\title{
Reforming College Sports: The Case for a Limited and Conditional Antitrust Exemption
}

\author{
Jayma Meyer \\ Indiana University Bloomington
}

Andrew Zimbalist

Smith College, azimbali@smith.edu

Follow this and additional works at: https://scholarworks.smith.edu/eco_facpubs

Part of the Economics Commons

\section{Recommended Citation}

Meyer, Jayma and Zimbalist, Andrew, "Reforming College Sports: The Case for a Limited and Conditional Antitrust Exemption" (2017). Economics: Faculty Publications, Smith College, Northampton, MA.

https://scholarworks.smith.edu/eco_facpubs/44 


\title{
Reforming College Sports: The Case for a Limited and Conditional Antitrust Exemption
}

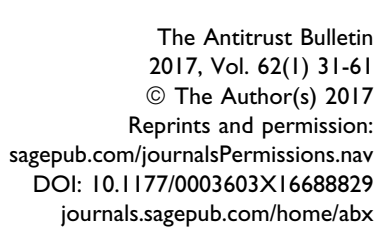

(SAGE

\author{
Jayma Meyer* and Andrew Zimbalist**
}

\begin{abstract}
College sports has been undergoing rapid commercialization and reorganization. This transformation has led to sharpening inequality among schools within and between divisions, unstable and unsustainable economics, and burgeoning legal challenges. It is not an exaggeration to state that intercollegiate athletics is at an economic and legal tipping point. This article first discusses the economic issues confronting college sports. It then turns to consider the plethora of litigation facing the National Collegiate Athletic Association (NCAA) and argues that antitrust and labor laws are inadequate means to respond effectively to the economic and legal challenges surrounding college sports. Finally, the article makes the case for a limited and conditional antitrust exemption for the NCAA that would promote the primacy of academics and the fair treatment of athletes.
\end{abstract}

\section{Keywords}

antitrust exemption, rule of reason, O'Bannon, college athletic department operating deficits, intercollegiate health and safety, intercollegiate academic and fairness reforms

\section{Introduction}

College sports has been undergoing rapid commercialization and reorganization. This transformation has led to sharpening inequality among schools within and between divisions, unstable and unsustainable economics, and burgeoning legal challenges. It is not an exaggeration to state that intercollegiate athletics is at an economic and legal tipping point. This article first discusses the economic issues confronting college sports. It then turns to consider the plethora of litigation facing the National Collegiate Athletic Association (NCAA) and argues that antitrust and labor laws are inadequate means to respond effectively to the economic and legal challenges surrounding college sports. Finally, the article makes the case for a limited and conditional antitrust exemption for the NCAA that would promote the primacy of academics and the fair treatment of athletes.

\footnotetext{
* Counsel, Simpson Thacher \& Bartlett LLP; and Visiting Clinical Professor of Sports Law, SPEA, Indiana University, Bloomington, IN, USA

** Robert A. Woods Professor of Economics, Smith College, Northampton, MA, USA
}

\section{Corresponding Author:}

Andrew Zimbalist, Robert A. Woods Professor of Economics, Smith College, Northampton, MA 01063, USA.

Email: azimbali@smith.edu 


\section{The Economic Environment}

\section{A. Background}

To many, it may seem that big-time college sports is running on a treadmill. Every year more money pours in-whether through new media contracts with national networks, regional sports networks, corporate sponsorships, the Football Championship Playoff (FCP), fatter donations, or new ticketing strategies - but the number of the 350-plus Division I or 128 Football Bowl Subdivision (FBS) programs reporting an operating surplus has stagnated around twenty. ${ }^{1}$ Moreover, according to the biannual NCAA Revenues and Expenses Report, the size of the median program operating deficit in FBS has been steadily growing in recent years, from $\$ 5.9$ million in 2004 , to $\$ 9.5$ million in 2010 , $\$ 12.3$ million in 2012 , and $\$ 14.7$ million in $2014 .^{2}$

It is important to understand what these operating deficits mean. They do not include (most) capital expenses, such as the debt service on stadiums, arenas, training facilities, or tutoring centers. ${ }^{3}$ Indeed, the 2005 study commissioned by the NCAA estimated that the median capital costs of FBS athletic programs exceeded $\$ 20$ million annually.

They also tend to exclude an array of indirect costs, such as a share of a university president's compensation, office rental and supplies, and staff. ${ }^{4}$ Part of the problem is that there are no established counting conventions, so despite instructions from the NCAA, each school uses its own interpretation of the proper accounting methodology. The point is that the reported operating deficits tend to be considerably smaller than actual fully accounted deficits. Some of the financial shortfalls may be offset by increased appropriations from state legislatures, increased student fees, or an uptick in donations to successful programs. This funding, however, is neither robust nor dependable. It applies in a positive way, if at all, to competitively successful programs, and applies in a negative way to unsuccessful programs.

Of course, to be a competitively successful program, schools need to commit to providing abundant resources in the areas of hiring big-name coaches, creating world-class facilities, recruiting aggressively, providing extensive academic tutoring, and so on. That is, with salary payments to athletes prohibited, the most effective way to recruit the best athletes is by providing successful coaches, lavish facilities, and effective support systems. Note that in professional sports in the United States, athlete

1. We define operating surplus as the NCAA does in its biannual Revenues and Expenditures report. That is, it refers to generated revenues (including donations) minus operating costs, where operating costs exclude most capital expenses. See NCAA, Revenues \& Expenses: 2004-2014 NCAA Division I Intercollegiate Athletics Programs Report 11, 24 (complied by Daniel L. Fulks, Ph.D., CPA, 2015), http://www.ncaa.org/sites/default/files/2015\%20Division\% 20I\%20RE\%20report.pdf [hereinafter NCAA, REVENUES \& EXPENSES 2015].

2. Note that these figures represent net generated revenue for the FBS athletic programs in each cited fiscal year. Id. at 24 .

3. There are no set accounting conventions for college athletic departments, and although the NCAA has been encouraging uniformity, there is still substantial variability among departments in their treatment of capital expenses. The most common practice appears to be that when debt service on facility loans are paid directly by the athletic department, they are included in operating costs. In contrast, when the debt service is paid by the university or the state, they tend not to be included.

4. Donations to the athletics program are included on the revenue side. It is also important to point out that the expense side can be overstated when student-athletes on scholarship cannot be replaced by full-paying students. In such a case, the tuition expense is overstated because it does not represent the out-of-pocket cost to the school. Two caveats to this observation are in order. First, while the marginal out-of-pocket cost of adding a football player to a classroom of a few dozen students may be close to zero, it is not close to zero if the alternative is for the school to drop from FBS, the top level of college football, to FCS, in which case there are twenty-five scholarship athletes affected or if the alternative is to drop to Division III or to drop football altogether, in which cases there are eighty-five scholarship athletes affected. For larger groups of students, extra classrooms, materials, teachers, and tutors are required, presenting substantially augmented costs. Second, if the alternative to enrolling an academically underprepared athlete is to bring in an intellectually gifted minority student from the inner city, then, although there is full scholarship in both cases, there is certainly an indirect cost in terms of the quality of the student body, the eventual productivity of the student when he or she joins the workforce, the intellectual environment in the classroom, and the reputation of the school. 
compensation is controlled by a system of salary caps, debt rules, luxury taxes, and revenue sharing. In college sports, the spending is displaced from athlete compensation to other areas where there are no constraints on spending. This is a system without the necessary restraints for financial success.

Unlike a typical commercial enterprise, college sports programs do not have stockholders who demand a profit at the end of each quarter so that the price of the company's stock will rise or that dividends may be paid out. Rather, college sports programs have stakeholders (e.g., boosters, season ticket buyers, alumni, administrators, students, and state legislators) who, above all else, want winning teams. The primary pressure placed on athletic directors (ADs) is to find a way to win, not a way to make profits. Moreover, ADs and coaches advance in their careers and are able to command higher and higher compensation packages only if they produce victorious teams. What this means is that when the typical AD at a Power Five conference school sees additional revenues entering the program, the first and dominant thought is: "How can I put that revenue to use to build a more successful program?" In the hypercompetitive world of big-time college sports and the arms race it engenders, there is always some additional enhancement that an $\mathrm{AD}$ is yearning to make. ${ }^{5}$

The result is that the system, even for the 128 richest FBS athletic programs in the country, has growing median operating deficits. In any given year, when properly accounted (e.g., including capital costs) there are probably only a half dozen or so schools that generate a true surplus in their athletic programs. ${ }^{6}$

It bears emphasis that the financial situation of intercollegiate athletics is growing increasingly dire, despite the rapid increase in revenues in recent years. The combination of sharpening inequality across schools and conferences, and enormous fees and costs (directly or indirectly) inflicted upon athletic programs as a result of various litigations, presents an increasingly problematic financial challenge. Changes in telecommunications technology threaten to undermine the long-standing, lucrative model of expanded basic-cable television and to reduce media revenue streams for college sports in the future. There are too many pressures on the system for it to avoid substantial reform.

\section{B. Growing Inequality Among Athletic Programs}

With the NCAA's long-standing national TV policy struck down on antitrust grounds in 1984 by the Supreme Court in NCAA v. Board of Regents of University of Oklahoma (Board of Regents), ${ }^{7}$ schools and conferences were left to fend for themselves. The NCAA television cartel was broken. The leading football colleges and conferences were cut free, and the weaker football colleges lost the protection of the previous NCAA plan.

The data in Table 1 illustrate the revenue distributional impact of the 1984 Board of Regents Supreme Court decision and the conference restructuring of the 1990s. During the eighteen years between 1962 and 1980 , there was a steady increase in relative revenue inequality across the top 150 college athletic programs, with the ratio of the top revenue program to the average (mean) revenue program increasing by 0.67 points. During the next seventeen years, 1980-1997, the ratio increased at a $50 \%$ faster rate, or by 1.00 points.

It is also noteworthy that the Supreme Court ruling was largely coincident with the explosion in popularity of cable television in the United States. Whereas in 1980 there were 15.5 million cable TV

5. Expenditures to increase the quality of intercollegiate teams do not increase output. They merely redistribute and generate additional revenue for the successful schools. With athlete pay suppressed, a majority of this revenue flows to coaches. Because of this peculiarity of college sports, putting caps on expenditures would not decrease consumer welfare. This is another reason that supports our call for a conditional and limited antitrust exemption.

6. Note that more than half of FBS football teams (55\% in 2013-2014) and roughly half of FBS men's basketball teams (50\% in 2013-2014) run an operating surplus. That is, a surplus before capital and certain indirect costs are included. But typical FBS athletic programs support fifteen to thirty sports, virtually all of which run a substantial operating deficit. The result is commonly a deficit for the entire athletics department.

7. Nat'l Collegiate Athletic Ass'n v. Bd. of Regents of Univ. of Oklahoma, 468 U.S. 85 (1984). 
Table I. Revenue Inequality Among the Approximately Top I50 Athletic Programs, 1962-1997. ${ }^{8}$

\begin{tabular}{lc}
\hline Year & Top School/Average School \\
\hline 1962 & 1.81 \\
1970 & 1.92 \\
1980 & 2.48 \\
1989 & 3.04 \\
1995 & 3.29 \\
1997 & 3.48 \\
\hline
\end{tabular}

Table 2. BS Football and Men's Basketball Revenue, 1997-2003. ${ }^{9}$

\begin{tabular}{lccc}
\hline FY & High & Average & Ratio (high/avg.) \\
\hline 1997 & $\$ 37,400,000$ & $\$ 10,500,000$ & 3.56 \\
1999 & $\$ 44,700,000$ & $\$ 12,200,000$ & 3.66 \\
2003 & $\$ 67,300,000$ & $\$ 17,300,000$ & 3.89 \\
\hline
\end{tabular}

homes (or $19.9 \%$ of TV households), by 1990 there were 52 million cable TV homes (or $56.4 \%$ of TV households). As is well known, cable television added a second revenue stream (monthly subscription fees) to the traditional advertising stream, and hence, its expansion helps to explain the rapid growth in television contracts for the elite football conferences in Division I.

Other factors promoting inequality include the Bowl Championship Series (BCS), the Football Championship Playoff (FCP), skewed revenue distributions from the NCAA, the emergence of conferenceowned regional sports networks (RSNs), and the explosion of network conference television contracts. Since its inception in 1998, and through 2014, the BCS allowed for preferential bowl access and sharply differential revenues to flow to the six original BCS (aka, automatic qualifier or AQ) conferences. The FCP extends the unequal distribution of revenues and roughly triples the amount of money distributed. ${ }^{10}$

Although the top/average revenue ratio series ends in 1997, it is possible to extend the trend through 2003 by reference to NCAA data for football and men's basketball programs. Table 2 shows that the ratio of the highest revenue program from football and men's basketball to the average revenue program steadily increased from 3.56 in FY 1997, to 3.66 in FY 1999 and to 3.89 in FY 2003.

Since 2003, the NCAA has not reported average (mean) revenues for athletic programs. Instead, it reports only median revenue. With the skewed revenue distribution that prevails in the FBS, the mean is typically considerably above the median, so these two data series are not comparable.

As shown in Table 3, the ratio of the highest to median in both football and basketball for FBS schools continues its steady ascent between FY 2004 and FY 2014. ${ }^{11}$

8. Andrew Zimbalist, Unpaid Professionals: Commercialism and Conflict in Big-Time College Sports 117 (1999). See also Mitchell H. Raiborn, NCAA, Financial Analysis of Intercollegiate Athletics (1970); M. Raiborn, NCAA, Revenues and Expenses of Intercollegiate Athletic Programs, 1970-1977, 1978-1981, 1981-1985, 1985-1989 (1990); Daniel Fulks, NCAA, Revenues and Expenses of Intercollegiate Athletic Programs, 1993 (1994); D. Fulks, NCAA, Revenues and Expenses of Division I and II Intercollegiate Athletic Programs, 1995, 1997 (1998).

9. Andrew Zimbalist, Inequality in Intercollegiate Athletics: Origins, Trends and Policies, 6 J. InTERCOLlegiate SPORT 5, 15 (2013).

10. Revenue distribution data prior to 2000 is scarce, and that which is available is generally tabulated with different metrics than that available since 2000. It is therefore difficult to obtain an accurate picture of how much inequality has increased over the decades. Further, due to inconsistent and incomplete accounting practices within athletic departments and the fact that a good deal of revenue and cost information is treated as proprietary, it is impossible even today to achieve a full and accurate picture of the extent of inequality. Nonetheless, it is possible to compile pieces of information from the periodic NCAA Revenues and Expenses reports, the Equity in Athletics Data Act (EADA) reports and other sources to assemble a broad outline of the trends and the status quo in revenue inequality among FBS programs.

11. NCAA, REVENUES \& EXPENSES 2015, supra note 1, at 27. 
Table 3. FBS Football and Men's Basketball Revenue, 2004-20I4 (millions of dollars). ${ }^{12}$

\begin{tabular}{lcccc}
\hline FY & Median Generated Revenue & Top Generated Revenue & Top/Median & Top - Median \\
\hline Football & & & & \\
2004 & 8.3 & 46.2 & 5.6 & 37.9 \\
2010 & 16.2 & 93.9 & 5.8 & 77.7 \\
2014 & 21.7 & 151 & 7.0 & 129.3 \\
Men's basketball & & & & \\
2004 & 3.2 & 16.5 & 5.2 & 13.3 \\
2010 & 4.8 & 25.9 & 5.4 & 21.1 \\
2014 & 5.8 & 40.6 & 7.0 & 34.8 \\
\hline
\end{tabular}

This pattern of inequality is underscored by considering the decile breakdown of revenues in football and men's basketball within the 124 FBS schools in FY $2014 .{ }^{13}$ In football, $40 \%$ of the programs had revenues below $\$ 7.56$ million in FY 2014, while in basketball $40 \%$ had revenues below $\$ 3.2$ million. ${ }^{14}$ Meanwhile, the bottom half of FBS schools are trying to remain competitive and are expanding their athletic spending. The average athletic spending per student athlete in FBS went from $\$ 63,000$ in 2004 , to $\$ 85,000$ in 2008 , to $\$ 105,000$ in 2012 , and to $\$ 116,000$ in $2014 .{ }^{15}$

As a result of the Football Championship Playoff and mammoth conference television deals (both networks and RSNs), only the schools in the Power Five conferences are generating enough revenues to supply competitive resources to their teams. FBS schools outside the Power Five continue to aspire to the "big time" by building new facilities, hiring high-priced coaches, and attempting to more aggressively recruit, but their prospects for promotion are practically nonexistent. They are wasting resources because, as noted earlier, even among the sixty-five schools in the Power Five, only about twenty are generating an operating surplus, and when capital and other indirect costs are included, the number of programs generating a surplus dwindles to roughly a half dozen. ${ }^{16}$

The inevitable outcome for the overwhelming majority of college athletic programs is that they drain the central educational budget of millions (or tens of millions) of dollars yearly. The drain is only getting larger over time. Universities have attempted to plug the financial leak by raising student fees, increasing tuition and seeking more taxpayer support from the state legislature. The situation is not financially, politically, or socially sustainable. Nor, as discussed below, is it legally effective.

\section{The Legal Environment}

\section{A. Overview}

Litigation tends to trigger NCAA rule changes. Sometimes just the threat of litigation causes reform. Other times, we see new rules after lengthy and expensive litigation that the NCAA has settled or lost. Many times these rules are at the margin (e.g., permitting unlimited snacks for athletes); other times they are more significant (e.g., permitting aid up to the cost of attendance). This is hardly an efficient or

12. Id.

13. By FY 2016, the number of FBS had grown to 128.

14. NCAA, REVENUES \& EXPENSEs 2015, supra note 1, at 27.

15. Id. at 22 .

16. To be sure, a prepublication draft of the 2016 NCAA Revenues and Expenses Report for the academic year 2014-2015 indicates that there were twenty-four athletic programs that experienced a net operating surplus in 2014-2015, the same number as in 2013-2014. The number of FBS athletic programs with a net operating surplus was eighteen in 2003-2004 and fourteen in 2008-2009. 
effective way to manage college sports; nor is it a satisfactory way to make important public policy decisions regarding higher education.

Litigation involving antitrust laws has been a particular thorn in the NCAA's side. The antitrust laws have been the basis for athletes and others to challenge rules - including payment and benefits to athletes for their play, the length and number of scholarships available to athletes, the length of competitive seasons, the selection of teams to participate in national championships, and the payment of assistant coaches. These litigations have had mixed results. Athletes also have resorted to labor laws to find a friendly basis for pursuing their claims and seeking payment for play and other reforms. Attempts under the Fair Labor Standards Act for college athletes to be declared employees have not yet succeeded at the national level. Attempts by Northwestern University football players to unionize, while finding success at a regional level in Chicago, failed at the national level.

These efforts, described below in detail, have helped create a tipping point. Indeed, while the Supreme Court has declined to hear the O'Bannon case, ${ }^{17}$ lower courts in Alston ${ }^{18}$ and Jenkins, ${ }^{19}$ or likely additional new cases, ${ }^{20}$ may fundamentally change the landscape of intercollegiate athletics by permitting payment and other benefits beyond the cost of attendance to athletes for their services. Without further Supreme Court guidance, outcomes of these cases are uncertain due to the murkiness in applying current legal frameworks. Moreover, the expense and effort involved in litigating these outcomes are enormous. All of this demonstrates the need for a new approach.

That solution is a limited and conditional antitrust exception. It would permit the NCAA and its member schools to impose certain rules such as prohibiting payment for play (e.g., salaries) to athletes without fear of violating the antitrust laws, while allowing certain types of payments and benefits (e.g., payments for third-party endorsements) to athletes. These exceptions would be provided if costspending measures are implemented (e.g., capping coaches' salaries and facilities spending) and player-centric measures are implemented (e.g., protecting the health, safety, and well-being of college athletes and requiring the primacy of academics in intercollegiate athletics). ${ }^{21}$ Thus, the proposed limited and conditional exception would promote socially desirable policies that otherwise might not be enacted due to the fear of litigation.

\section{B. Antitrust Laws and the Judicially-Created Rule of Reason Framework Are Difficult to Apply to NCAA Rules}

The antitrust laws and their judicially created frameworks are not easily applied to intercollegiate sports. The Sherman Act prohibits all contracts, combinations, or conspiracies in restraint of trade that are unreasonable, and it was designed to govern commercial activities. Colleges and universities, most of which are nonprofit organizations, enter into contracts and combinations (i.e., rules) in order jointly to compete in sports. ${ }^{22}$ In antitrust cases involving intercollegiate sports, the threshold question is whether the challenged rule is fundamentally commercial in nature. If it is, the overriding question is whether the rule is unreasonable because it causes significant anticompetitive effects.

17. O'Bannon v. Nat'1 Collegiate Athletic Ass'n, 7 F. Supp. 3d 955 (N.D. Cal. 2014), aff'd in part, vacated in part, 802 F.3d 1049 (9th Cir. 2015), cert. denied (Oct. 3, 2016).

18. Alston v. Nat'l Collegiate Athletic Ass'n, Case No. 4:14-md-02541 (N.D. Cal. 2015).

19. Jenkins v. Nat'l Collegiate Athletic Ass'n, Case No. 4:14-cv-02758-CW (N.D. Cal. 2014).

20. It is especially likely that new cases will be brought in circuits other than the Ninth Circuit where O'Bannon was decided. See infra Section III D.

21. See Matthew J. Mitten, James L. Musselman, \& Bruce W. Burton, Targeted Reform of Commercialized Intercollegiate Athletics, 47 SAn Diego L. Rev. 779 (2010), for a similar proposal.

22. While nonprofit organizations are not categorically exempt from the Sherman Act, "when they perform acts that are the antithesis of commercial activity, they are immune from antitrust regulations." United States v. Brown Univ., 5 F.3d 658, 665 (3d Cir. 1993). 
Both of these questions require an analysis of factors that are not necessarily comparable and application of a framework originally designed for businesses that does not apply easily to intercollegiate sports. There are no bright line rules, no clean-cut balancing tests with objective criteria, and few other mechanisms to make these judgments unambiguously. With respect to the threshold question, courts must evaluate rules with claimed noncommercial purposes (e.g., eligibility rules that preserve amateurism), but which have major commercial effects. While there are no clear definitions of what constitutes a "commercial" restraint, it includes "almost every activity from which [an] actor anticipates economic gain." 23

Few people would deny that college athletics, especially FBS football and Division I (DI) men's basketball, are commercial enterprises. In fact, despite the economic deficits experienced by many athletic departments, as described above, over the last few decades the commerciality of college sports has accelerated. ${ }^{24}$ College sports is estimated to be at least a $\$ 12$ billion industry, and growing. Indeed, the NCAA admits that FBS football teams and DI men's basketball teams "command significant commercial interest. That interest exerts pressures that could undermine the distinct and longstanding nature of college athletics, driving them away from being a scholastic endeavor and towards being a professional one." 25 Similarly, the Seventh Circuit Court of Appeals opined in Agnew v. NCAA:

No knowledgeable observer could earnestly assert that big-time college football programs ... do not anticipate economic gain from a successful recruiting program. Despite the nonprofit status of premier athletesfull scholarships in exchange for athletic services - are not noncommercial since schools can make millions of dollars as a result of these transactions. ${ }^{26}$

Once a rule is found to be fundamentally commercial, the court must then address the question of whether it is an unreasonable restraint on trade. Here, because the nature of the product - competitive sports - requires joint activity among individual institutions (i.e., a team cannot play by itself), courts apply a rule of reason analysis to answer the question. ${ }^{27}$ The judicially created rule of reason framework involves three steps. First, the plaintiff has the burden of proving that the restraint creates anticompetitive effects. ${ }^{28}$ Second, the burden shifts to the defendant to prove procompetitive benefits flowing from the restraint. ${ }^{29}$ Third, if the defendant's justifications are "sufficient," ${ }^{30}$ the burden shifts

23. Phillip E. Areeda \& Herbert Hovenkamp, Antitrust Law 9260 b, at 250 (2000).

24. The recent agreement (May 2016) between UCLA and Under Armour for a fifteen-year, \$280 million merchandising/ sponsorship agreement is the largest in the history of collegiate sponsorship and highlights the paradox of commercialized college sports. See Lucy Schouten, UCLA Lands NCAA's Biggest Merchandise Contract Ever (May 24, 2016), http:// www.csmonitor.com/USA/USA-Update/2016/0524/UCLA-lands-NCAA-s-biggest-merchandise-contract-ever.

25. Brief in Opposition to Petitioner's Petition for Writ of Certiorari at 1, O'Bannon v. Nat'1 Collegiate Athletic Ass'n, 802 F.3d 1049 (2016) (No. 15-1167).

26. Agnew v. Nat'l Collegiate Athletic Ass'n, 683 F.3d 328, 340 (7th Cir. 2012).

27. Traditionally courts have analyzed agreements under either a per se illegality standard or a rule of reason analysis (or variation thereof like a "quick look" rule of reason). Ordinarily, horizontal price fixing and output limitation are automatically per se illegal. However, where horizontal restraints on competition are essential if the product is to exist at all, courts typically apply a rule of reason analysis.

28. Some courts say the plaintiff must prove "significant" anticompetitive effects (e.g., O'Bannon v. Nat'l Collegiate Athletic Ass'n, 802 F.3d 1049, 1072 (9th Cir. 2015)) or "substantial" anticompetitive effects (e.g., Law v. Nat'l Collegiate Athletic Ass'n, 902 F. Supp. 1394 (D. Kan. 1995), aff'd 134 F.3d 1010 (10th Cir. 1998) (emphasis added).

29. Some courts articulate that the challenged restraint be reasonably necessary to achieve a legitimate objective. See, e.g., United States v. Brown Univ., 5 F.3d 658, 678-79 (3d. Cir. 1993).

30. Some courts state the procompetitive effects, at this stage, must offset (e.g., Cal. Dental Ass'n v. Fed. Trade Comm'n, 526 U.S. 756, 782 (1999) (Breyer, J., dissenting)); countervail (e.g., FTC v. Ind. Fed'n of Dentists, 476 U.S. 447, 459 (1986); Bd. of Regents, 468 U.S. 85 (1984)); outweigh (e.g., Eastman Kodak Co. v. Image Tech. Servs., 504 U.S. 451, 486 (1992); Atl. 
back to the plaintiff to show that the challenged conduct is not reasonably necessary to achieve the legitimate benefits or that comparable procompetitive benefits could be achieved through a less restrictive alternative (LRA). ${ }^{31}$ Courts, at least implicitly, attempt to assess the legitimacy of (or weigh or balance) these pro and anticompetitive effects and the LRA, and therefore determine whether the virtues of the anticompetitive conduct justify the adverse impact. ${ }^{32}$ Their judgment turns on whether the dominant or net effect of the restraint, or of the LRA, is to promote competition or hinder it. ${ }^{33}$ This informs the ultimate question required by the Sherman Act of whether the challenged behavior is unreasonable.

Although the rule of reason framework - designed to analyze the reasonableness of a restraint - has been embedded in antitrust law for decades, its precise parameters are vague, and its application is inconsistent. ${ }^{34} \mathrm{As}$ a matter of fact, an operative concept in the Sherman Act - reasonableness - lacks precision. With little guidance on how to quantitatively weigh and balance harms with procompetitive effects and analyze alternatives, many courts purport to apply the framework but, rather subjectively, reach their own conclusions. ${ }^{35}$ Indeed, in the second step, with respect to commonly asserted procompetitive justifications in antitrust cases involving intercollegiate sports (such as amateurism, integration of athletics and academics, and competitive balance), lawyers and courts frequently either insufficiently quantify, or fail to quantify at all, the justifications. Instead, they rely on qualitative assessments of the benefits, making them nearly impossible to weigh against quantitative anticompetitive effects. ${ }^{36}$ Accordingly, some courts rather mechanically assume that the procompetitive benefits are sufficient and turn to the third step of analyzing whether less restrictive alternatives exist. This step also suffers from vagueness. Here, too, quantifiable measures are frequently absent, and there is little agreement

Richfield Co. v. USA Petroleum Co. 495. U.S. 328, 342 (1990); United States v. Microsoft Corp., 253 F.3d 34, 59 (D.C. Cir. 2001); Harriston v. Pac. 10 Conf., 101 F.3d 1315, 1319 (9th Cir. 1996); or justify (e.g., the 10th Circuit's discussion of anticompetitive effects in Law, 134 F.3d at 1019-21). The court in Law also stated that "[j]ustifications ... may be considered only to the extent that they tend to show that, on balance, 'the challenged restraint enhances competition." Id. at 1021 (emphasis added) (citations omitted). On the other hand, some courts make no judgment at this point, and move directly to step three. See C. Scott Hemphill, Less Restrictive Alternatives in Antitrust Law, 116 Colum. L. Rev. 927, 941-42 (2016).

31. Some courts require the plaintiffs to show a least restrictive alternative. See, e.g., Areeda \& Hovenkamp, Antitrust LAw, supra note 23, ๆ 1505(b), ๆ 913.

32. Some courts state that the balancing occurs once all the burdens are met. See, e.g., Law, 134 F.3d, at 1019. Some courts engage in balancing only if no LRA is demonstrated. See Hemphill, Less Restrictive Alternatives, supra note 30 , at 941. Indeed the Model Jury Instructions state that fact finders must balance benefits and harms if no LRA exists. Am. Bar Ass'n Section of Antitrust Law, Model Jury Instructions in Civil Antitrust Cases, Instruction 3D (2005). And some cases state that no balancing is required once a LRA is proven. See Hemphill, Less Restrictive Alternatives, supra note 30, at 976-77.

33. Cal. Dental Ass'n, 526 U.S. at 771; Geneva Pharm. Tech. Corp. v. Barr Labs., Inc., 386 F.3d 485, 507 (2d Cir. 2004).

34. This article does not engage in the scholarly debate about the proper parameters of the rule of reason, including the role and timing of balancing, but instead argues that its uncertain and inconsistent articulation and application supports our call for a conditional and limited antitrust exemption.

35. As Professor Areeda has explained: "[S]olutions are elusive where allowing the restraint would threaten competition with significant harm of substantial magnitude but where preventing it would apparently deprive society of significant and substantial benefits." P. Areeda, The "Rule of Reason" in Antitrust Analysis: General Issues 3 (Federal Judicial Center 1981), http://www.fjc.gov/public/pdf.nsf/lookup/antitrust.pdf/\$file/antitrust.pdf. And he further stated: "There is no general formula by which one can say what balance of harms and benefits justifies categorical prohibition. ..." Id. at 23. See also Gary R. Roberts, The NCAA, Antitrust, and Consumer Welfare, 70 Tul L. Rev. 2631, 2656 (1966) (discussing the lack of clarity in case law as to how to weigh and balance procompetitive effects and anticompetitive harms and stating: "All a factfinder could do is intuitively sense how 'bad' or 'good' an effect is and then subjectively decide whether his or her sense is that the 'good' effects are greater than the 'bad' based on his or her own life experiences and values.").

36. See Rebecca Haw Allensworth, The Commensurability Myth in Antitrust, 69 VAnd. L. Rev. 1 (2016) (discussing the debate surrounding balancing trade-offs required as part of the rule of reason and stating: "What are offered in antitrust cases as procompetitive and anticompetitive effects are typically qualitatively different, and trading them off is as much an exercise in judgment as mathematics. But despite the inevitability of value judgments in antitrust cases, courts have perpetuated a commensurability myth, claiming to evaluate 'net' competitive effect as if the pros and cons of a restraint of trade are in the same unit of measure. The myth is attractive to courts because it appears to allow the law to avoid the murky, value-laden compromises struck by other areas of regulation."). 
on how much less restrictive the alternative must be - whether it must be the least anti-competitive restriction, whether it must result in the same procompetitive effects as the challenged restraint, whether it must not impose additional costs, how probable the benefits must be, and so forth. As a result, like in earlier steps, frequently courts' rather subjective view of the proposed alternative restriction prevails. ${ }^{37}$

Thus, unquestionably, the fact finder's role in balancing the procompetitive and anticompetitive effects and alternative restraints is fraught with ambiguity. ${ }^{38}$ In fact, despite language to the contrary in many of the cases, and perhaps due to the problems with quantification, true balancing may be rarely, if ever, actually performed: "[R]ule of reason balancing is perhaps the greatest myth in all of U.S. antitrust law.",39 Some scholars have gone so far as to suggest balancing should be avoided unless absolutely necessary:

Once we have identified the types and magnitudes of threats to competition, legitimate objectives, and possible alternatives, we have still to reach an "on balance" judgment about "reasonableness." Because both theory and data are usually insufficient and because quantification in terms of a common denominator is usually impossible, balancing will inevitably be crude and should be avoided unless absolutely necessary. ${ }^{40}$

Accordingly, the judicially created analytical framework for the rule of reason, designed to bring clarity to analyzing the reasonableness of restraints under the antitrust laws, is infested with vagueness and subjectivity. Without converting pro and anticompetitive effects, whether of the original restraint or a less restrictive restraint, into the same measurements, courts weigh incommensurate values ${ }^{41}$ or even ignore the process of balancing the effects.

\section{The Supreme Court and Its Progeny Do Not Impart Clarity}

The Supreme Court in the seminal case, NCAA v. Board of Regents, established that the two-step process discussed above applies to NCAA rules. First, courts analyzing antitrust challenges to NCAA regulations should distinguish between commercial and noncommercial NCAA regulations. ${ }^{42}$ Second, if the rules fall into the commercial bucket, courts should apply the rule of reason to determine if those rules unreasonably restrain competition. ${ }^{43}$

The Supreme Court in Board of Regents rather quickly concluded that the challenged contracts that schools jointly negotiated with television networks were commercial rules. However, it made a point to state that not all NCAA rules are commercial:

The specific restraints on football telecasts that are challenged in this case do not, however, fit into the same mold as do rules defining the conditions of the contest, the eligibility of participants, or the

37. See Herbert Hovenkamp, Antitrust Balancing, 12 N.Y.U. J.L. \& Bus. 369, 370 (2016). ("Even if the things requiring balancing did come in cardinal units, most times the courts would not have the tools necessary to make and apply the measurements. Instead, balancing approaches are usually binary rather than cardinal. They are more like off and on switches that go in one direction or the other.").

38. Andrew I. Gavil, William E. Kovacic \& Jonathan B. Baker, Antitrust Law in Perspective: Cases, Concepts and Problems in Competition Policy 207 (2d ed. 2008).

39. Andrew I. Gavil, Burden of Proof in U.S. Antitrust Law, 1 Issues In COMPETITION L. \& PoL'y 125, 147 (ABA Section of Antitrust Law 2008). See also Michael A. Carrier, The Real Rule of Reason: Bridging the Disconnect, 16 BYU L. REv. 1265, 1267 (1999); Michael A. Carrier, The Rule of Reason: An Empirical Update For The 21st Century, 16 Geo. Mason L. Rev. 827, 828 (2009).

40. Phillip E. Areeda \& Herbert Hovenkamp, Fundamentals of Antitrust Law $§ 15.04$ (A) (4th ed.) (2016 Supplement).

41. Judge Scalia described this problem in another context as "judging whether a particular line is longer than a particular rock is heavy." Bendix Autolite Corp. v. Midwesco Enters., Inc., 486 U.S. 888, 897 (1988) (Scalia, J., concurring). See also Robert H. Bork, The Rule of Reason and the Per Se Concept: Price Fixing and Market Division, 74 YALE L. J. 775, 839 (1965).

42. Nat'l Collegiate Athletic Ass'n v. Bd. of Regents of Univ. of Oklahoma, 468 U.S. 85, 98-99 (1984).

43. Id. at 103-04. 
manner in which members of a joint enterprise shall share the responsibilities and the benefits of the total venture. $^{44}$

This dicta, which was irrelevant to the key issue in the case-legality of the rules regarding TV contracts - opened the door to the NCAA arguing in later cases that its rules, especially "eligibility" rules, are not commercial.

Next, the Court explained that the rule of reason, not the per se illegal rule, should be used because the case "involves an industry in which horizontal restraints on competition are essential if the product is to be available at all." "45 Applying the first step of the rule of reason framework, the Court found that the restraint limited output (reduced the number of games televised) and restricted prices (set a minimum aggregate price) - "paradigmatic examples of restraints of trade that the Sherman Act was intended to prohibit." 46 Shifting to the second step of the rule of reason, the Court stated that the contracts, as "hallmarks of anticompetitive behavior," placed a "heavy burden" on the NCAA to establish an affirmative defense that justifies the deviation from a free market. ${ }^{47}$ The Court then upheld the lower court's findings that the procompetitive justifications of protecting a live audience, establishing an efficient marketing strategy, and preserving competitive balance were not supported by the evidence, and thus did not "offset" the anticompetitive limitations on price and output. Because step two was not satisfied, the Court never reached consideration of a less restrictive alternative, although it stated that it agreed with the lower court's conclusion that if the procompetitive justifications had been supported by the evidence, they could be achieved by a less restrictive alternative. ${ }^{48}$ Other than the Supreme Court's admonition that the NCAA carried a "heavy burden" at the second stage, it provided no specific guidance on what weights to assign to or how to balance the pro and anticompetitive effects. Unlike most litigated cases, here, the anticompetitive effects were undeniably strong and the procompetitive effects absent.

While the Court's application of the rule of reason was quite straightforward given the particular facts, its opinion included some discourse that has caused much debate in subsequent cases. Particularly, dicta about payments to athletes, like its dicta noted above about eligibility rules, have stirred confusion and unpredictability. Explaining that the distinction between professional sports and college athletics justified the application of the rule of reason, ${ }^{49}$ the Court expressed that college athletes "must not be paid, must be required to attend class, and the like." ${ }^{, 0}$ The Court did not analyze whether such rules would be unreasonable under the burden-shifting framework. Rules regarding payments to athletes were irrelevant to the issue at hand - the legality of the rules regarding TV contracts. Yet it is that dicta that the NCAA has regarded as controlling in subsequent cases that explicitly analyze restraints that prohibit payments to athletes.

Accordingly, the Supreme Court's holding has limited precedential value regarding (1) the determination of whether particular rules are commercial (since the restraint there was so obviously commercial)

44. Id. at 117 (emphasis added).

45. Id. at 101 .

46. Id. at $107-08$.

47. Id. at 113 .

48. Id. at 97 .

49. The Supreme Court stated: "One clear effect of most, if not all, of these regulations [including those relating to eligibility, recruiting, and scheduling] is to prevent institutions with competitively and economically successful programs from taking advantage of their success by expanding their programs, improving the quality of the product they offer, and increasing their sports revenues. Yet each of these regulations represents a desirable and legitimate attempt 'to keep university athletics from becoming professionalized to the extent that profit making objectives would overshadow educational objectives.' Significantly, neither the Court of Appeals nor this Court questions the validity of these regulations under the Rule of Reason." Id. at 123 (citations omitted).

50. Id. at 102 . 
and (2) the precise application of the rule of reason to subsequent cases that have mixed anticompetitive and procompetitive effects (since the effects there were so apparently anticompetitive-restraining prices and output - and the proffered justifications irrelevant to the restraint). While virtually every court that has considered the antitrust legality of NCAA rules since Board of Regents has attempted to apply it, without more precise guidance, predictably, there has been insufficient consensus.

Certain courts have given great deference to the dicta in Board of Regents. For example, they have found NCAA rules, such as rules prohibiting the use of agents, to be noncommercial, and therefore held that the Sherman Act does not apply. They explicitly base their conclusions on the NCAA's argument that the rules are "eligibility" rules that implicate the NCAA's requirement of amateurism (even if they also have a commercial impact). ${ }^{51}$

On the contrary, especially given the pervasiveness of commercialism in FBS football and DI men's basketball, courts more recently have held that a variety of NCAA rules, such as rules limiting the number of athletic scholarships and their time period, are commercial and subject to the Sherman Act despite the NCAA's arguments that the rules are necessary to preserve amateurism and a clear demarcation between college and professional sports. For example, in Agnew v. NCAA, ${ }^{52}$ a class of football players challenged the NCAA limits on the number of athletic scholarships that schools could award per team and the one-year scholarship rule. The Seventh Circuit rejected the NCAA's argument that the rules were noncommercial and held that the rule of reason applied. Significantly, the court was skeptical about the NCAA's reliance on amateurism to justify the restraint, stating that "whether or not a player receives four years of educational expenses or one year... he is still an amateur." ${ }^{, 53}$ The court did not further analyze this issue. Given the procedural posture of the case-a motion to dismiss - the court was required to accept the allegations as true and only to determine the plausibility that the allegations stated a claim. ${ }^{54}$

Not surprisingly, courts find that rules with more direct monetary significance like setting specific salaries are easier to analyze and conclude that they are commercial, and are unreasonable restraints in violation of the Sherman Act. ${ }^{55}$ For example, attempts by the NCAA to set salaries of assistant coaches were analyzed under a quick rule of reason analysis and found to be illegal in Law v. NCAA. ${ }^{56}$ There, part-time men's basketball coaches challenged an NCAA regulation labeling part-time coaches as "restricted-earnings coaches" and limiting their compensation to $\$ 16,000$ annually (a reduction of approximately $70 \%$ for some part-time coaches). ${ }^{57}$ The court held that the

51. See, e.g., Bassett v. Nat'l Collegiate Athletic Ass'n, 528 F.3d 426, 433-34 (6th Cir. 2008) (discussing NCAA recruiting regulations); Smith v. Nat'l Collegiate Athletic Ass'n, 139 F.3d 180 (3d Cir. 1998) (discussing NCAA graduate transfer rules); Gaines v. Nat'l Collegiate Athletic Ass'n, 746 F. Supp. 738 (M.D. Tenn. 1990) (discussing NCAA restrictions on agents). See also Areeda \& Hovenkamp, Antitrust Law, supra note 23, ๆ 262.

52. Agnew v. Nat'l Collegiate Athletic Ass'n, 683 F.3d 328 (7th Cir. 2012).

53. Id. at 344. See also Banks v. Nat'l Collegiate Athletic Ass'n, 977 F.2d 1081, 1099 (7th Cir. 1992) (Flaum, J., dissenting) ("The NCAA continues to purvey ... an outmoded image of intercollegiate sports that no longer jibes with reality. The times have changed. College football ... is also a vast commercial venture that yields substantial profits for colleges ... "). To be noted: NCAA rules now permit multiyear scholarships.

54. Ultimately, the Seventh Circuit upheld the District Court's dismissal on the basis that the alleged markets ("bachelor's degrees" and "student athlete labor") were unclear and the complaint did not adequately define the relevant market on which the rules had an anticompetitive effect. See also Rock v. Nat'1 Collegiate Athletic Ass'n, 928 F. Supp. 2 d 1010 (S.D. Ind. 2013) (refusing to certify a class of DI football recruits and holding that rules that limited scholarships to one year at a time and that capped the number of football scholarships are subject to the Sherman Act (same basic allegations as in Agnew)).

55. Professional leagues that have collective bargaining agreements which provide salary caps on teams, rookies, etc. are permitted to enter into such price fixing agreements as a result of the nonstatutory labor exemption from the antitrust laws. But, colleges and universities do not have a similar antitrust exception. As discussed below, unionization of college athletes and collective bargaining do not appear likely to be an option in college sports.

56. Law v. Nat'l Collegiate Athletic Ass'n, 902 F. Supp. 1394 (D. Kan. 1995), aff'd 134 F.3d 1010 (10th Cir. 1998).

57. Id. at 1014 . 
alleged procompetitive cost-cutting justifications were not sufficient and the price fixing restrictions were illegal. ${ }^{58}$

\section{Recent Cases Seek Clarity}

The fuzziness in applying the antitrust laws and the judicially created rule of reason framework to NCAA rules, especially those rules that potentially have mixed effects and purposes - for example, socially desirable justifications but clear anticompetitive impact-is starkly illustrated in several recent cases: O'Bannon, Jenkins, and Alston.

I. O'Bannon. O'Bannon's now-tortured history began with a class action complaint in 2009 filed in the Northern District of California. ${ }^{59}$ The complaint challenged the NCAA's rules prohibiting purported classes of FBS football and DI men's basketball players from receiving payments for their names, images, and likenesses (NILs) in video games and live or archived television broadcasts. The NCAA rules prohibiting payments to athletes beyond grant-in-aid (GIA) scholarships did not specifically address, but subsumed, payments for NILs. After an enormous amount of legal maneuvering, and five years after the complaint was filed, the Honorable Judge Wilken issued a ninety-nine-page opinion in 2014, finding the rules to be commercial and, thus, subject to the Sherman Act and an unreasonable restraint of trade. ${ }^{60}$

The NCAA in O'Bannon had attempted to classify its no-payment rules as noncommercial "eligibility" rules that were necessary to protect the amateur product of college athletics. As such, and relying on Board of Regents dicta, the NCAA argued the rules were not subject to the Sherman Act and accordingly were legal. Judge Wilken rejected this and found that the NCAA was a cartel that engages in commercial restraints. ${ }^{61}$

Judge Wilken then applied the rule of reason to determine whether the alleged prohibitions violated the Sherman Act. She summarized the law by stating that "[a] restraint violates the rule of reason if the restraint's harm to competition outweighs its procompetitive effects." ${ }^{\circ 2}$ And she said it was appropriate to rely on a "burden-shifting framework to conduct this balancing."63

First, she found that the plaintiffs demonstrated that the prohibitions were a restraint with an anticompetitive effect - a price-fixing agreement. That is, athletes were prohibited from negotiating group licenses for their NILs and received zero compensation for them. ${ }^{64}$ Next, under the second step, the burden

58. See also White v. Nat'l Collegiate Athletic Ass'n, Case No. CV 060999 (C.D. Cal. 2008) (applying the Sherman Act to allegations that the grant-in-aid (GIA) scholarship cap violated antitrust laws. After the NCAA's motion to dismiss was denied and class certification granted, the NCAA settled for $\$ 10$ million plus requirements that athletes could more easily access a \$218 million fund already existing). Cf. Banks v. Nat'l Collegiate Athletic Ass'n, 977 F.2d 1081, 1089-90 (7th Cir. 1992) (applying the Sherman Act and upholding no-draft and no-agent eligibility rules); McCormack v. Nat'l Collegiate Athletic Ass'n, 845 F.2d 1338 (5th Cir. 1988) (applying the Sherman Act and upholding rules restricting compensation because they are a desirable and legitimate attempt to keep athletes from being professionalized).

59. NCAA Player Likeness, 4:09-CV-1967-CW, No. 1158-277 (N.D. Cal. 2015) (which is the consolidation of Keller v. Electronic Arts, 4:09-CV-01967-CW (N.D. Al. 2015) and O’Bannon v. Nat'1 Collegiate Athletic Ass'n, 4:09-CV-03329CW (N.D. Cal. 2015)).

60. O'Bannon v. Nat'l Collegiate Athletic Ass'n, 7 F. Supp.3d 955 (N.D. Cal. 2014), aff'd in part, vacated in part, 802 F.3d 1049 (9th Cir. 2015), cert. denied (Oct. 3, 2016).

61. Id. at 988 .

62. Id. at 985 (quoting Tanaka v. Univ. of S. Cal., 252 F.3d 1059, 1066 (9th Cir. 2001)).

63. Id. at 985 .

64. Id. at 973 . 
switched to the NCAA to demonstrate that there were compensating procompetitive justifications for its restrictive rules. The NCAA relied on four justifications; to wit, its rules were necessary to protect:

- amateurism,

- integration of athletics with academics and the rest of the student body,

- competitive balance among schools, and

- output or viewership. $^{65}$

Judge Wilken accepted as valid the first two of these justifications, finding that amateurism played a "limited" role in maximizing consumer demand, ${ }^{66}$ and integration of athletics and academics was a "narrow" procompetitive goal of increasing the quality of athletes' education. ${ }^{67}$ She rejected the last two justifications on the basis that there was an insufficient relation between them and the restraint. ${ }^{68}$ Judge Wilken did not reveal an in-depth balancing analysis to support her conclusion that the first two proffered procompetitive effects were "sufficient" and may increase consumer demand for college athletics or quality of educational services, despite her earlier comment that typically courts apply the burden shifting framework to conduct a balancing of harm and procompetitive effects. ${ }^{69}$ Instead, she said that because the defendant established two sufficient procompetitive benefits, it was appropriate to move to the third step required under the rule of reason that places a burden on the plaintiffs to demonstrate that there are other and better ways through less restrictive means to accomplish the procompetitive justifications. ${ }^{70}$ More particularly, she said the plaintiffs must show that an alternative is substantially less restrictive and as effective without significantly increased costs. ${ }^{71}$ While not revealing any explicit balancing here either, her use of "substantially" and "significantly" indicates some type of weighing, ${ }^{72}$ Judge Wilken found two less restrictive means were available to fulfill the NCAA's stated procompetitive justifications of amateurism and integration:

- payment of scholarships up to cost of attendance (COA) (an increase between $\$ 2,000$ and $\$ 6,000$ per year depending on the school over the previous GIA amount); and $^{73}$

- payment of up to $\$ 5,000^{74}$ a year to be held in trust for when the athlete leaves or graduates from college, with the requirements that all athletes on a team receive the same amount and that the funds be generated from group licenses.

65. Id.

66. Id. at 1001 .

67. Id. at 1003 .

68. Id. at $1002,1004$.

69. Id. at 985 .

70. Judge Wilken stated that if the NCAA had failed to meet its burden in step two, she would not have addressed step three: the availability of less restrictive alternatives. Id. at 1004-05.

71. Id. at 1005 .

72. Accordingly, the court conducted some type of balancing, at least implicitly, in steps two and three of the burden-shifting framework.

73. GIA includes room, board, tuition, fees, and required books for courses. COA adds miscellaneous expenses such as travel to and from campus, other books and supplies, laundry expenses, etc. Schools determine their respective COA based on a federally mandated formula. Given the discretion available in applying the formula, some schools are calculating the applicable amount on the high side and allegedly are gaining recruiting advantages. The COA, however, is limited by what is offered to other nonathlete scholarship students. O'Bannon, 7 F. Supp. 3d, at 965, 974.

74. Judge Wilken's opinion states that she was enjoining schools from prohibiting payments that are capped at less than $\$ 5,000$. $I d$. at 1008. While discussion of a cap at less than $\$ 5,000$ created some confusion, it is clear she meant that the cap could not be more than $\$ 5,000$, that is, schools must be allowed to pay up to $\$ 5,000$. See, e.g., the parties' briefs to the Ninth Circuit. Brief for the National Collegiate Athletic Association, O'Bannon v. Nat'l Collegiate Athletic Ass'n, 802 F.3d 1049 (2014) (Nos. 14-16601, 14-17068); Plaintiff-Appellees' Opposition Brief in Response to National Collegiate Athletic Association's Opening Appellate Brief, O'Bannon v. Nat'l Collegiate Athletic Ass'n, 802 F.3d 1049 (2015) (Nos. 14-16601, 14-17068); Reply Brief for the National Collegiate Athletic Association, 802 F.3d 1049 (2015) (Nos. 14-16601, 14-17068). 
Although celebrated by some as a big win for the plaintiffs, it was somewhat of a hollow victory because by the time of the decision, the NCAA's rules already had changed to permit scholarships up to the COA. Plus, the trust fund stipends did not help the athletes while they were in college and had other limitations as described above. The true win was to future plaintiffs in that a court had explicitly held that the NCAA rules prohibiting payments to athletes beyond the direct costs in GIA, even if called "eligibility rules," are rules with commercial effects and are unreasonable pursuant to a rule of reason antitrust analysis under the Sherman Act.

Both sides, then, had reason to be dissatisfied and shifted gears to pursue a hotly debated appeal to the Ninth Circuit. The Ninth Circuit, after extensive briefing by the parties, eleven amici curiae briefs, ${ }^{75}$ and a lengthy hearing, issued its decision in September $2015 .^{76}$ Judges Bybee and Quist and Chief Judge Thomas agreed that the restriction of no-payments for NILs was a commercial restraint subject to the Sherman Act. This was a loss for the NCAA on a fundamental premise. Further, the Ninth Circuit disagreed with the NCAA's claim that under Board of Regents, its "amateurism" rules were valid as a matter of law. Instead, the Ninth Circuit said that Board of Regents required such rules to be analyzed under the rule of reason.

In applying the three-step burden-shifting framework, first, the Ninth Circuit agreed with the District Court that the restraint had a "significant" anticompetitive effect by eliminating price competition among schools. ${ }^{77}$ Moving to the second step in the rule of reason analysis, it accepted that amateurism and integration were procompetitive justifications because they preserve the popularity of intercollegiate sports and broadened choices, respectively. Third, the Ninth Circuit considered the proposed alterative restraints. It upheld Judge Wilken's injunction that the NCAA could restrict the schools' ability to award scholarship amounts above the COA. The Ninth Circuit agreed that this was "substantially" less restrictive than a rule prohibiting payments beyond GIA and would not "significantly" increase costs. ${ }^{78}$ The panel's reasoning focused on the necessity of amateurism to college sports: (1) amateurism requires no payment to athletes, so there would be no amateurism if there were payments and (2) payments up to the COA were "tethered" to academics and, therefore, preserved the concept of amateurism. ${ }^{79}$

However, the panel split on the issue of trust fund stipends for NIL rights, with the majority finding they violated principles of amateurism because they were untethered to academics. Chief Judge Thomas's dissent on this issue challenged the artificiality of the majority's distinction and detailed the evidence that showed that small amounts of cash payments (beyond COA) provided to athletes after they left school would not harm the principle of amateurism. Plus, Chief Judge Thomas pointed out that amateurism, a "nebulous" concept, is relevant as a procompetitive justification in an antitrust analysis only to the extent it relates to consumer interest (a quantitative effect). ${ }^{80}$ He stated there was no showing that such small, deferred payments would harm consumer interest.

75. The amici represented a wide variety of interests, from antitrust and economic scholars to the American Council on Education.

76. O’Bannon v. Nat'l Collegiate Athletic Ass'n, 802 F.3d 1049 (9th Cir. 2015).

77. Id. at $1070-72$.

78. Id. at $1074-75$.

79. Judge Bybee explained: "The difference between offering student-athletes education-related compensation and offering them cash sums untethered to educational expenses is not minor; it is a quantum leap. Once that line is crossed, we see no basis for returning to a rule of amateurism and no defined stopping point. ... At that point the NCAA will have surrendered its amateurism principles entirely and transitioned from its 'particular brand of football' to minor league status." Id. at 1078-79 (quoting Bd. of Regents, 468 U.S. at 101-02).

80. Id. at 1083 (Thomas, J., concurring in part, dissenting in part). 
Interestingly, at no point did the Ninth Circuit discuss or engage in any explicit balancing. ${ }^{81}$ Indeed, the majority's conclusion stated: “[w] $[\mathrm{w}$ en ... regulations truly serve procompetitive purposes, courts should not hesitate to uphold them." ${ }^{82}$ However, it stressed that a restraint is illegal where it is "patently and inexplicably stricter than is necessary," 83 implying that some quantification and balancing must be conducted.

Again, both sides had reason to be dissatisfied. Accordingly, after the plaintiffs' request for an en banc rehearing to the full Ninth Circuit Court of Appeals was denied, ${ }^{84}$ in a somewhat unusual consensus on the need for review, both the plaintiffs and the NCAA submitted petitions for writ of certiorari to the Supreme Court. ${ }^{85}$ On October 3, 2016, the Supreme Court announced it would not accept certiorari. ${ }^{86}$ The Ninth Circuit's decision remains intact, resulting in continued uncertainty generally about the reach of the Court's 1984 holding in Board of Regents and the proper application of the rule of reason to NCAA rules, including the extent to which amateurism justifies a restraint on player compensation, the parameters of the less restrictive alternative analysis and whether, when, and what balancing should take place. More specifically, there continues to be uncertainty, especially outside the Ninth Circuit, about whether schools can agree that college athletes cannot be paid more than cost of attendance scholarships and whether the compensation must be tethered to college expenses. As a result, the NCAA is left vulnerable to more challenges. ${ }^{87}$

2. Jenkins and Alston. Among the most recently filed class action cases to challenge the NCAA's no-pay rules ${ }^{88}$ are Jenkins v. NCAA [and the five Power conferences] (Jenkins) ${ }^{89}$ and Alston v. NCAA [and the five Power conferences plus six other conferences] (Alston). ${ }^{90}$ The cases allege that the NCAA and conferences systematically colluded to set a cap on the amount of compensation a school may provide athletes. The complaints seek to open the compensation issue to the free market. They seek an injunction that strikes down the alleged illegal restraints without specifying what other rules would be lawful. ${ }^{91}$

81. While not stating that he was engaging in any balancing, by noting that the proposed LRA was substantially less restrictive, Judge Thomas, concurring in part and dissenting in part, made a judgment that involved weighing the effects. Id. at 1080-82.

82. Id. at 1079 .

83. Id. at 1075 .

84. Plaintiff-Appellees' Petition for Rehearing En Banc, Nat'l Collegiate Athletic Ass'n v. O’Bannon, 802 F.3d 1049 (9th Cir. 2015), rehearing denied, Oct. 14, 2015.

85. The Plaintiffs submitted a petition on March 14, 2016. Petition for Writ of Certiorari, O'Bannon v. Nat'l Collegiate Athletic Ass'n, 802 F.3d 1049 (Mar. 14, 2016). The NCAA submitted a petition on May 13, 2016. Petition for Writ of Certiorari, Nat'l Collegiate Athletic Ass'n v. O'Bannon, 802 F.3d 1049 (May 13, 2016).

86. O’Bannon v. Nat'l Collegiate Athletic Ass'n, 802 F.3d 1049 (9th Cir. 2015), cert. denied (Oct. 3, 2016).

87. In its Petition for Certiorari, the NCAA showed its frustration with the current litigations: "The NCAA should not have to undergo a full trial (and years of litigation) or face treble damages whenever a plaintiff or counsel hits on a supposedly better way to administer college athletics." Petition for Writ of Certiorari, No. 15-1388, at 26-27 (clarifying that the precedent would "preclude[] potentially endless antitrust challenges to NCAA rules").

88. NCAA Bylaw 15.1 as amended in 2015 , provides that "[a] student-athlete shall not be eligible to participate in intercollegiate athletics if he or she receives financial aid that exceeds the value of the cost of attendance..." NCAA, 2009-10 NCAA Division Manual, 174 (2009), http://www.ncaapublications.com/productdownloads/D110.pdf.

89. Case No. 4:14-CV-0278-CW (N.D. Cal. 2016). The five power conferences are the Atlantic Coast Conference; Big 12 Conference; Big Ten Conference; Pac-12 Conference; and Southeastern Conference.

90. Case No. 4:14-md-02541-CW (N.D. Cal. 2015). The six other conferences are the American Athletic Conference; Conference USA; Mid-American Conference; Mountain West Conference; Sun Belt Conference; and Western Athletic Conference. The original Alston complaint was consolidated with four other complaints and a consolidated complaint was filed. Steve Berkowitz, Court Filing: NCAA, Conferences Say Scholarships Could Be Reduced, USA ToDAY SPORTS (May 1, 2015), http://www.usatoday.com/story/sports/college/2015/05/01/ncaa-suit-shawne-alston-martin-jenkins-kessler-nigelhayes-claudia-wilken/26685565/.

91. Consolidated Pls.' Memorandum in Opposition to Defendants' Motion for Judgment on the Pleadings, at 2, Jenkins v. Nat'1 Collegiate Athletic Ass'n, No. 15-80219 (9th Cir. June 1, 2016) (Doc. 396). 
However, the plaintiffs' lawyers, possibly reacting to criticisms of the O'Bannon decision that the court had micromanaged the NCAA, have suggested that a possible alternative is that the conferences could unilaterally decide appropriate levels of pay.

While Jenkins and Alston have been coordinated for pretrial purposes in the Northern District of California before Judge Wilken (the same judge who decided O'Bannon), there is a significant difference between the cases. Jenkins seeks only injunctive relief. ${ }^{92}$ Alston seeks not only injunctive relief, but also monetary damages for four years (amount of time permitted under the applicable statute of limitations) of the difference between GIA and COA scholarships. The Plaintiffs have alleged that this comes to $\$ 240$ million. Judge Wilken in December 2015 certified three classes of athletes for the injunctive relief claims in Jenkins and Alston: FBS football players, DI men's basketball players, and DI women's basketball players. Certification of the proper classes for the monetary damage claims in Alston continues to be litigated.

There was some initial jockeying once Jenkins was coordinated with Alston. One result is that the lawyers for the Jenkins plaintiffs are now co-counsel with the plaintiffs in Alston for the claims seeking injunctive relief. However, it remains unclear how, when or where the cases will be tried. The injunctive relief sought in Jenkins and Alston may end up being tried together. Or, all the claims may be tried together. Another possibility is that Jenkins may go back for trial to the Northern District of New Jersey where it was originally filed.

Importantly, these cases, if successful, may fundamentally change college sports as we know them. They will be decided by courts that must answer the messy questions: (1) Which rules fundamentally are commercial? (2) If they are commercial, what are the anticompetitive and procompetitive justifications $?^{93}$ (3) Are there less restrictive alternatives? (4) What is the net effect of all this? To the extent that the claims remain before Judge Wilken, the Ninth Circuit's decision in O'Bannon is binding, including that the NCAA's rules on compensation to intercollegiate athletes are subject to the Sherman Act. On the other hand, among other things, the plaintiffs will be challenged by the Ninth Circuit's holding that payments must be tethered to academics. ${ }^{94}$

\section{E. Cases Based on Labor Laws Provide No Relief}

Finding the antitrust laws inhospitable to demands to be paid for their services beyond a COA scholarship, athletes have resorted to the labor laws. For example, in Berger v. $N C A A,{ }^{95}$ the University of Pennsylvania women's track and field athletes alleged that they and a class of current and former Division 1 athletes are "employees" under the Federal Labor Standards Act (FLSA) and therefore entitled to be paid for playing, just like students in work-study programs are paid. ${ }^{96}$ The District Court in Southern Indiana granted the defendants' motions to dismiss on February 16, 2016, and stated that the relationship between athletes and institutions of higher education is fundamentally an "educational experience," more akin to extracurricular student-run programs than to work-study programs. On December 5, 2016, the Seventh Circuit affirmed, agreeing with the District Court that intercollegiate sports are extracurricular "play" not "work," "97 and that their economic reality is based on the revered tradition of amateurism. While the Seventh Circuit agreed

92. The Jenkins case is frequently referred to as the Kessler case in the popular press. Jeffrey Kessler represents the Plaintiffs.

93. The Jenkins' attorneys have made it clear that they intend to quantify the question of whether amateurism leads to increased output.

94. Although a distinction is that the O'Bannon Plaintiffs only sought payments for NILs.

95. 2016 U.S. Dist. LEXIS 18194 (S.D. Ind. Feb. 16, 2016) (No. 1:14-cv-1710-WTL-MJD).

96. This case originally was captioned Sackos/Anderson v. NCAA. A former soccer player at the University of Houston alleged that the NCAA and DI universities conspired to violate the Fair Labor Standards Act by failing to at least pay a federal minimum wage of $\$ 7.25$ per hour. No. 1:14-cv-1710-WTL-MJD (filed Oct. 22, 2014) (S.D. Ind.). Sackos was replaced by Berger et al. as the plaintiffs.

97. Berger v. Nat'l Collegiate Athletic Ass'n, 2016 WL 7051905 at 8 (7th Cir. Dec. 5, 2016). 
that student athletes are not employees and should not be paid, the concurring opinion muddied the waters by stating that the economic reality and tradition of amateurism in revenue producing sports like DI men's basketball and FBS football may dictate a different result. ${ }^{98}$ Accordingly, we can expect to see more cases brought under the FLSA, especially by revenue producing athletes.

\section{F. Efforts to Unionize Fail}

Much of the joint activity in the professional sports leagues is exempted from the antitrust laws under a nonstatutory labor exemption. Professional players, through respective unions, negotiate collective bargaining agreements with owners and agree on numerous noncommercial details (e.g., conduct policies) and restrictive commercial rules (e.g., player and team salary caps and reserve clauses) that otherwise would be prohibited under the Sherman Act.

Attempting to gain a similar right to negotiate terms and conditions of play, a group of football players at Northwestern University, under the guidance of the College Athletes Players Association (CAPA), filed a petition in 2013 to gain the right to unionize.

Peter Sung Ohr, Regional Director in Chicago, National Labor Relations Board, after extensive briefing and a hearing, held that the Northwestern football players who received scholarships had a right to unionize. He concluded that the athletes were employees under the National Labor Relations Act because, inter alia, they are subject to special rules. For instance, they are required to: ${ }^{99}$

- live in on-campus dormitories for freshman and sophomore years,

- obtain permission from the athletic department to obtain outside employment,

- disclose to the department information regarding the vehicle they drive, and

- abide by a social media policy.

Hearing Officer Ohr also found that the players are prohibited from engaging in numerous types of activity such as: ${ }^{100}$

- swearing in public,

- transferring to another school in order to play football immediately, and

- profiting off their names, images and likenesses.

And he found, among other things, that the players were subject to many other rules, none of which were applicable to the general student body; for example, they must: ${ }^{101}$

- wear certain clothes when traveling to away games,

- attend study hall a certain number of hours, and

- stay within a six-hour radius of campus on game days.

Also crucial to Regional Director Ohr's conclusion that the scholarship football players were employees was the amount of time they devoted to football. Five pages of Hearing Officer Ohr's decision detailed those time commitments. He found that the time commitments totaled fifty to sixty

\footnotetext{
98. Id. at $8-9$.

99. Northwestern Univ. v. Coll. Athletes Players Ass'n, NLRB No. 13-RC-121359 (Mar. 26, 2014).

100. Northwestern Univ., NLRB No. 13-RC-121359, at 5. A similar case, Dawson v. Nat'l Collegiate Athletic Ass'n, was brought on September 26, 2016, in the Northern District of California. Dawson, No. 3:16-cv-05487 (N.D. Cal. Sept. 26, 2016). The plaintiff, a former USC football player has brought the case on behalf of himself individually, and purported classes of college football players, seeking to be defined as employees and to be paid both minimum wages and overtime pay.

101. Northwestern Univ., NLRB No. 13-RC-121359, at 5.
} 
hours per week during training camp, forty to fifty hours per week during the season, and twenty-five hours in a number of two-day periods traveling to and from games and competing in the games. ${ }^{102}$

Based on these time commitments, the control exercised over the players (through the many rules such as listed above) and benefits received by the university from the players (e.g., the Northwestern football program generated $\$ 30.1$ million in operating revenue and $\$ 21.7$ million in operating expenses in the 2012-2013 academic year), Ohr concluded that the scholarship football players were "employees" and entitled to vote on whether to unionize and be represented for collective bargaining purposes by CAPA. ${ }^{103}$

This decision was heralded as a breakthrough for the protection of the rights of college athletes. Such optimism was short-lived, as the NCAA immediately appealed to the full NLRB in Washington, D.C. Many observers expected the full Board to rather quickly uphold the regional director's conclusions based on his careful and detailed findings.

Instead, the Board took seventeen months to "punt." It failed to address the merits of the matter and found it would not promote labor harmony to accept jurisdiction. In particular, the NLRB made three key observations: (1) intercollegiate athletics was in a transitional phase in 2015; (2) allowing unionization would have engendered systemic instability by permitting only athletes at the 17 private colleges out of 128 FBS schools to unionize; and (3) there was a need to resolve the labor market issues and academic tensions in the current system. ${ }^{104}$ Significantly, the NLRB made a call to the U.S. Congress to clarify the institutional structure of college sports by concluding with a plea that it was addressing the "case in the absence of explicit congressional direction regarding whether the Board should exercise jurisdiction" and emphasizing that it was leaving open the issue of whether they might find jurisdiction in another case involving scholarship players. ${ }^{105}$

\section{G. Congressional Intervention Is Necessary}

In addition to the inconsistent application of the unsatisfactory analytical rule of reason framework as applied in the sports area (as discussed above), other reasons ${ }^{106}$ support the need for congressional action in the form of a limited and conditional antitrust exemption. These include that resources are misallocated and spent on litigation instead of academic support or health and safety assistance for athletes' and courts are ill-equipped to make important decisions impacting the future of college sports.

I. Excessive time, money, and effort are spent on legal matters. Time, money, and effort by the NCAA, conferences, and schools should be spent on ensuring the integrity of college sports, the health and safety of college athletes, and maximizing the academic experience of these students. Instead, the NCAA, conferences, and schools are all spending excessive time, money, and effort defending themselves in the many attempts by athletes to be paid (and receive other benefits) for their play, whether

102. Id. at 6-7.

103. Id. at 13 .

104. Id. at 4 .

105. Subsequently, in August 2016, the NLRB held that graduate and undergraduate teaching and research student assistants were statutory employees pursuant to the National Labor Relations Act. Columbia Univ. and Graduate Workers of Columbia-CWC, UAW, NLRB No. 02-RC-143012 (2016). Significantly, this decision overruled Brown Univ., 342 NLRB 483 (2004), a case that the NLRB in Northwestern said was distinguishable because "scholarship players bear little resemblance to the graduate student assistants." Northwestern had heavily relied upon Brown in its briefs. Northwestern Univ., NLRB No.13-RC-121359, at 3, 13.

106. See Stephen F. Ross \& Matt Mitten, A Regulatory Solution to Better Promote the Educational Values and Economic Sustainability of Intercollegiate Athletics, 92 OR. L. REv. 837, 868-69 (2014). 
via the antitrust or labor laws as detailed above. ${ }^{107}$ The $O^{\prime}$ Bannon case highlights the misplacement of resources. The complaint was filed in July 2009 and the merits were not resolved until October 2016 when the Supreme Court declined to accept the writs for certiorari. The following demonstrates the highly litigious - "leave no stone unturned"-approach by both sides in the O'Bannon case: ${ }^{108}$

- Trial Court:

- 1,161,043 pages of documents were produced by the NCAA.

- Over seventy-six depositions were conducted.

- At least ten motions to dismiss were made.

- Twenty-three live witnesses testified at trial (plaintiffs had nine witnesses while the NCAA had fifteen witnesses).

- 287 trial exhibits were admitted.

- Trial lasted three weeks.

- Trial transcript was 3,395 pages.

- At least seventy-six motions were made by the parties.

- Along the way, there were five Notices of Interlocutory Appeal to the Ninth Circuit (including the appeal of the District Court's final decision).

- Three post-trial briefs were filed.

- Permanent injunction findings of fact and conclusions of law were ninety-nine pages long.

- Ninth Circuit:

- Both sides appealed the permanent injunction decision to the Ninth Circuit.

- Eleven amici curiae briefs were submitted in connection with the appeal of the permanent injunction.

- Plaintiffs submitted a motion for an en banc hearing.

- Both sides hired additional renowned appellate lawyers.

- Supreme Court:

- Both sides submitted petitions for writ of certiorari and briefs in opposition.

- Four amici curiae briefs were submitted.

Further, the parties have hotly debated the plaintiffs' fees and costs. The plaintiffs made a request for $\$ 50.2$ million, of which Judge Wilken ordered the NCAA to pay slightly more than $\$ 40$ million. ${ }^{109}$ The NCAA challenged that amount in both the District Court and Ninth Circuit. ${ }^{110}$ As of November 2016, there was no final decision.

Significantly, the Fee Request is only for the plaintiffs' attorney fees and costs through the trial. It does not include, inter alia, the plaintiffs' fees and costs post trial, all the defendants' fees and costs,

107. In fiscal year 2015, the NCAA's lobbying expenses, while not all devoted to the issues addressed herein, were $\$ 580,000$ an amount that exceeded the three previous years combined. And, much more significantly, the NCAA's legal expenses totaled \$25 million, double from the previous year. Indeed, the NCAA's CFO, Kathleen McNeely, told USA Today Sports: "I was naïve in believing that our legal fees would start to come down, I'm willing to admit that. It's a litigious environment." Steve Berkowitz, NCAA Spends \$25 Million on Outside Legal Fees, Double from Previous Year, USA Today SPORTs (June 11, 2016), http://www.usatoday.com/story/sports/college/2016/06/11/ncaa-legal-fees-obannon/ 85772006/.

108. Plaintiffs' Motion for Attorneys' Fees, Costs, and Expenses and Memorandum in Support Thereof, O'Bannon v. Nat'l Collegiate Athletic Ass'n, 7 F. Supp. 3d 955 (N.D. Cal. 2014) (No. 4:09-cv-03329-CW). See also Declaration of Michael D. Hausfeld in Support of Antitrust Plaintiffs' Motion for Attorneys' Fees, Reimbursement of Expenses, and Class Representative Incentive Awards, Nos. 4:09-cv-1967-CW, 4:09-cv-3329-CW (N.D. Cal. 2014).

109. O’Bannon v. Nat'l Collegiate Athletic Ass'n, No. C09-3329 CW, 2016 WL 1255454, at 1 (N.D. Cal. Mar. 31, 2016), appeal docketed, No. 16-15803 (9th Cir. May 2, 2016).

110. Id. 
and the time and expenses of internal NCAA lawyers and witnesses, among others. Since the Fee Request was made in 2015, both sides have invested substantially more time and expense in this one case, including the appeal to the Ninth Circuit and petitions for writ of certiorari to the Supreme Court.

Further, the Fee Request does not reflect any of the fees, costs and settlement amounts paid in related claims. The O'Bannon plaintiffs settled with defendants Electronic Arts and the Collegiate and Licensing Co. (the NCAA licensing arm) for $\$ 40$ million. The NCAA settled with the Keller plaintiffs (the video game plaintiffs) for $\$ 20$ million. The Keller claims that had been initially consolidated with the O'Bannon claims concerned an alleged violation of publicity rights as a result of the use of NCAA FBS players' and basketball players' names, images and likenesses in certain NCAA-branded videogames by Electronic Arts. ${ }^{111}$

Time, money, and effort, unquestionably, would be much better spent on ensuring the integrity of college athletics and reinforcing the primacy of academics. O'Bannon and its extremely lengthy litigation history illustrate a misplacement of resources. There are no indications that Jenkins and Alston or any of the cases brought under the labor laws will be any less vigorously litigated.

2. The judicial system is ill-suited to make important decisions impacting the future of college sports. Most courts and applicable judicial processes have limited practical capacity to fully address the desirability and scope of rules protecting college sports. ${ }^{112}$ Rules of evidence, constrained testimony, limited briefing, and artfully constructed oral arguments are not conducive to full analyses of all the stakeholders' information, positions, and implications thereof necessary to resolving these important public policy matters. ${ }^{113}$ Further, as discussed in detail above in Section III, courts have latitude in determining whether particular rules are commercial and subject to the Sherman Act. Moreover, the longstanding framework for applying the rule of reason framework, particularly analyses and balancing of procompetitive and anticompetitive effects and less restrictive alternatives, is immensely difficult to apply in any context, and much more so in this context.

a. Scholarly analyses demonstrate the need for congressional intervention. Recent scholarly analyses have focused on the difficulties in applying the antitrust laws to the NCAA's rules on payments to intercollegiate athletes. For example, Professor Scott Hemphill in his recent article "Less Restrictive

111. In re NCAA Student-Athlete Name \& Likeness Licensing Litigation, 724 F.3d 1268 (9th Cir. 2013) (holding that the First Amendment did not prevent a right-of-publicity claim arising from the use of college-football players' NILs in videogames).

112. Among other issues, Supreme Court Justices have waded into economic issues that the Justices appear to insufficiently understand. The Court in Board of Regents wrote: "The television plan protects ticket sales by limiting output-just as any monopolist increases revenue by reducing output." Nat'l Collegiate Athletic Ass'n v. Bd. of Regents of Univ. of Oklahoma, 468 U.S. 85, 116-17 (1984). The Justices misapprehended basic microeconomic theory. Monopolists produce on the elastic portion of the demand curve, meaning that a certain percent increase in price (from reduced output) yields a larger percent decrease in quantity demanded. Since revenue equals price times quantity, revenue decreases when a monopolist decreases output. Profits, however, grow because costs decrease by more than revenue decreases.

113. For example, a rule permitting athletes to be paid their fair market value could result in the reduction of overall revenues and, as a consequence, the demise of many women's intercollegiate teams and non-revenue-producing men's teams. Revenues from big-time football and basketball, particularly at D1 schools, are currently redistributed to support women's and non-revenue-producing men's teams. Indeed, in O'Bannon, the NCAA argued that a procompetitive justification for not paying FBS football players and D1 basketball players was the positive revenue sharing on women's sports. The court refused to permit that argument because it did not affect the relevant market at issue. See O'Bannon, 802 F.3d at 1070 . Order Denying Motion for Leave to File Motion for Reconsideration, In re NCAA Student-Athlete Name \& Likeness Licensing Litigation [O’Bannon] (N.D. Cal 2014) (Docket No. 1033). See also Antitrust Plaintiffs' Opposition to Defendant NCAA's Motion to Sever, or Alternatively to Continue Trial, In re NCAA Student-Athlete Name \& Likeness Licensing Litigation, 2014 WL 1873825 (N.D. Cal. 2014) No. 4:09-cv-1967-CW; but see Order Denying Motion to Sever Trial Issues or Continue Trial Date and Setting Dates, Keller v. Nat'1 Collegiate Athletic Ass'n, 4:09cv-01967 (N.D. Cal 2014) (Docket No. 1029) (consolidated with O'Bannon). 
Alternatives in Antitrust Law," 114 discussed the "anxiety about balancing" in this context and precisely explained some of the difficulties:

Although modern antitrust law has economics at its core, applying cost-benefit analysis to real-world conduct is not a straightforward task. Assessing the net effect of mixed conduct is hard. It is challenging to measure the effects of, say, a loss in competition for players arising from limits on compensation. (How much would the players receive? Which ones? What would be the change in output, if any?) Measuring the benefits to competition among sports leagues is also hard. (Would fans otherwise watch less college sports? How much worse is the next-best use of fans' time? What are the effects on advertising markets?) A full analysis requires an assessment of size, probability, and error costs. Such quantification, at least in a rough sense, is necessary in order to compare the two effects.

Implementation is a further, potentially difficult issue. Judges are generalists, see antitrust cases only rarely, are generally unfamiliar with the practice and industry at issue, and are therefore not well equipped to evaluate these effects. The limited fact-finding capacity of courts is a familiar refrain, as is courts' limited capacity in antitrust cases, particularly if the fact-finding is performed by a jury. ${ }^{115}$

Professor Herbert Hovenkamp, in discussing O'Bannon and the "problems at work" in collegiate sports, advocated that antitrust laws are not the solution and "any fix that addresses all of [the] problems will probably have to come from Congress...."116 In fact, numerous law professors and economists, in addition to the court of public opinion, have recognized that a new course is necessary to resolve this complex issue in intercollegiate sports. ${ }^{117}$

b. Judges recognize the need for congressional intervention. Judges, too, have increasingly recognized the difficulties in applying antitrust laws and legal frameworks to intercollegiate sports and have suggested that Congress may need to intervene.

Judge Wilken, in the District Court of Northern District of California, after spending five years as the Judge in the O'Bannon case, expressed her dissatisfaction with the ability of antitrust laws to resolve the NIL pay for play issue:

College sports generate a tremendous amount of interest, as well as revenue and controversy. Interested parties have strong and conflicting opinions about the best policies to apply in regulating these sports. Before the Court in this case is only whether the [NCAA can restrict athletes' payment for NILs to GIA scholarships].

To the extent other criticisms have been leveled against the NCAA and college policies and practices, those are not raised and cannot be remedied based on the antitrust causes of action in this lawsuit. It is likely that the challenged restraints, as well as other perceived inequities in college athletics and higher education

114. Hemphill, Less Restrictive Alternatives, supra note 30, at 947.

115. Id. (citations omitted).

116. Hovenkamp, Antitrust Balancing, supra note 37, at 379.

117. See, e.g., Brian L. Porto, Neither Employees Nor Indentured Servants: A New Amateurism for a New Millennium in College Sports, 26 Marq. Sports L. Rev. 301 (2016); Nathaniel Grow, Regulating Professional Sports Leagues, 72 WaSH. \& LeE L. Rev. 573, 574 (2015); Daniel E. Lazaroff, An Antitrust Exemption for the NCAA: Sound Policy or Letting the Fox Loose in the Henhouse? 41 Pepp. L. Rev. 229 (2014); Stephen F. Ross \& Matt Mitten, A Regulatory Solution, supra note 106, at 844; Stephen F. Ross, Radical Reform of Intercollegiate Athletics: Antitrust and Public Policy Implications, 86 TuL. L. REv. 933 (2012); Mitten, Musselman, \& Burton, Targeted Reform, supra note 21, at 779; Roberts, The NCAA, Antitrust, and Consumer Welfare, supra note 35; Ralph D. Russo, As NCAA Fends Off Challenges, Antitrust Exemption Debated, THE WAsh. Times (May 21, 2015), http://www.washingtontimes.com/news/2015/may/21/as-ncaa-fends-off-challengesantitrust-exemption-d/. Len Elmore, Exempt the NCAA from Antitrust, The Chronicle of Higher Education (Dec. 11, 2011), http://www.chronicle.com/article/Exempt-the-NCAA-From-Antitrust/130073/. See also Sharon Terlep, Colleges May Seek Antitrust Exemption for NCAA, WaLl StREET Journal (July 30, 2014, 1:27 p.m.), http://www.wsj.com/articles/ colleges-may-seek-antitrust-exemption-for-ncaa-1406741252. 
generally, could be better addressed as a policy matter by reforms other than those available as a remedy for the antitrust violation found here. Such reforms and remedies could be undertaken by the NCAA, its member schools and conferences, or Congress. ${ }^{118}$

Indeed, Judge Wilken, two years after she issued her opinion in O'Bannon, said: "Any rule of reason case almost is a tabula rasa, because you're weighing apples against oranges." 119 She further said that because the antitrust analysis has many complications, she did not know how she would have designed jury instructions if the O'Bannon case had proceeded to a jury trial. ${ }^{120}$

Similarly, Chief Judge Thomas, Ninth Circuit Court of Appeals, in O'Bannon pointed out the difficulty in resolving whether athletes should be paid for play: "The national debate about amateurism in college sports is important. But our task as appellate judges is not to resolve it. Nor could we."121 Also, as noted above, the NLRB, in declining to accept jurisdiction over whether the Northwestern University football players could unionize, implied that the issue of whether athletes are employees and therefore should be paid might be most appropriately decided by Congress: "[W]e address this case in the absence of explicit congressional direction regarding whether the Board should exercise jurisdiction." 122

Quite simply, the adversarial system is not the place to make certain meaningful and appropriate decisions in the intercollegiate sports arena where certain cooperation among competitors and jointly enacted rules are necessary to the product and where their elimination would have numerous direct and unintended consequences.

\section{Reform Proposal: A Limited and Conditional Antitrust Exemption}

Intercollegiate athletics, as discussed above, are increasingly commercial but still a hybrid model, containing elements of both professionalism and amateurism. The tension between these elements has yielded hypocrisy, waste and exploitation. Effective reform will necessarily move the system toward one end of the spectrum or the other.

Moving toward professionalism and pay for play poses many challenges. First, how would the system be structured? With 17 private schools and 111 public schools in FBS, collective bargaining seems beyond reach. Without collective bargaining, there is no nonstatutory labor exemption, so it is unclear how restraints on a free labor market (such as salary or team caps) could be imposed lawfully. If restraints were fashioned by a court order (such as in O'Bannon), then college labor markets would be determined by judges and lawyers. Absent a rational and democratically determined set of labor market restraints that takes into account more than just one or several isolated challenged restraints, an

118. O'Bannon, 7 F. Supp. 3d at 1008-09.

119. Jeff Zalesin, Antitrust Rule Of Reason Cases Tough To Try, Judges Say, Competition L. 360 (Apr. 6, 2016, 6:06 p.m.), http://www.law360.com/articles/781389/antitrust-rule-of-reason-cases-tough-to-try-judges-say.

120. Id.

121. The O'Bannon Plaintiffs in their Petition for Certiorari (at 15) compared the NCAA's reliance on amateurism to the defendant's defense in United States v. Trans-Missouri Freight Ass'n, 166 U.S. 290, 340 (1897), wherein the Court said that the antitrust laws do not permit the defendant to establish a legally cognizable interest in the suppression of competition: "These considerations are, however, not for us. If the act ought to read as contended for by the defendants, congress is the body to amend it, and not this court, by a process of judicial legislation wholly unjustifiable." Petition, supra note 85.

122. Northwestern Univ. \& College Athletes Players Ass'n, 2015 NLRB LEXIS 613, 204 L.R.R.M. 1001, 2014-15 NLRB Dec. (CCH) P 15,999, 362 NLRB No. 167 (N.L.R.B. Aug. 17, 2015). Additionally, the court in Berger v. NCAA cautioned that whether "college athletes... should be compensated in some way" is not properly resolved by a court but instead is a broader "societal debate." Berger v. Nat'1 Collegiate Athletic Ass'n, 2016 U.S. Dist. LEXIS 18194, at n. 5. Cf. PGA Tour, Inc. v. Martin, 532 U.S. 661, n. 51 (2001) ("[P]etitioner's questioning of the ability of courts to apply the reasonable modification requirement to athletic competition is a complaint more properly directed to Congress ...."). 
open labor market would evolve into a free for all. For example, it could accelerate the rapacious recruiting of seventeen-year-old high school athletes. This, in turn, would eventually mean that aggressive player agents would be hanging around high school athletic facilities to sign up fifteenand sixteen-year-olds. The goal of subordinating athletics to the educational mission of colleges, now hanging on a thin thread, would be obliterated.

Second, there is little question that only the few biggest star athletes on FBS football and male basketball teams are economically exploited. Some of these athletes produce a value of over a million dollars per year for their schools. ${ }^{123}$ In exchange, they receive a full-ride scholarship that may be worth up to $\$ 60,000$ or $\$ 70,000$ per year (assuming optimistically that they actually receive an education). The balance of athletes on these squads are either lightly exploited; not exploited; or, for the majority of the eighty-five football scholarship athletes, receive compensation in the form of scholarship, first-class travel, and perquisites in excess of the value they produce. If there is concern over athlete exploitation, it should be focused on the few very top star athletes. But these athletes are professionals in training and will soon be earning multi-million-dollar salaries in the professional leagues. The major issue they confront is the possibility of career-ending injury. This problem can be addressed by offering the star athletes income replacement insurance for a career-ending disability (such insurance is now permitted by NCAA rules, but the athlete must pay for it) ${ }^{124}$ and by permitting regulated third-party payments for NILs to those stars.

Third, introducing pay for play will be expensive. The median operating deficit in FBS was already $\$ 14.7$ million in FY 2014, and growing. With capital and indirect costs, the median deficit balloons to more than $\$ 20$ million or \$30 million. If athletes become employees, then schools will have to pay salaries as well as make payments for social security, workmen's compensation, unemployment insurance, and other benefits. Athletes will have to pay income and social security taxes on their compensation. Schools may lose some of their favorable Unrelated Business Income Tax (UBIT) treatment by the IRS along with other tax preferences. In the end, the educational budget and learning process will suffer further damage. ${ }^{125}$

Fourth, there is the question of how pay for play will affect the popularity of college sports as amateur competition. Some argue that if college athletes are paid, fans will perceive intercollegiate athletics as they perceive minor league sports. Accordingly, attendance and television contracts will fall. Others argue that a similar claim was made when there was discussion of paying Olympic athletes in the 1970s, but the Olympics has only grown in popularity since the 1980s, when Olympic athletes were first allowed to compete as professionals. ${ }^{126}$ In truth, while compelling arguments can be made on both sides of the debate, no one knows what the impact on fandom will be from the professionalization of college sports.

123. With NBA and NFL stars earning from $\$ 10$ million to $\$ 20$ million annually, and with NBA and NFL teams generating between 2.5 and 10 times as much revenue as the top thirty college basketball and football teams, it is apparent that with a normal labor market, the top college hoops and gridiron players would be earning (and hence, producing a value) well in excess of $\$ 1$ million.

124. The NCAA provides loans to star athletes who are most likely to be drafted by professional leagues in order to purchase career ending insurance through its Exceptional Student-Athlete Disability Insurance Program.

125. Eventually, if college athletes were paid, the astronomical compensation now paid to college coaches and athletic administrators would be reduced, alleviating some of the cost pressure. See the discussion in Gerald Gurney, DonNa A. Lopiano, \& Andrew Zimbalist, Unwinding Madness: What Went Wrong with College Sports—and How to Fix It chs. 7-8 (2017).

126. In 1984, the IOC voted to allow the International Federation of each sport to set the eligibility rules for their sport, within some limits. In 1987, the IOC voted to permit professional tennis players to participate in the Games, and in 1989, the IOC extended the welcome to all professional athletes. See Andrew Zimbalist, Circus Maximus: The Economic Gamble Behind Hosting the Olympics AND the World Cup ch. 2 (2015). It should be noted, however, that the compensation of Olympic athletes in the United States is determined by each sport's federation and tends to be nominal. Thus, almost all of the Olympic athletes receive below a livable wage, and while they are "paid," the perception of the public may still be the athletes are not professionals. Top Olympic athletes from other countries, especially Asian countries, receive more robust compensation, and those who win medals usually receive hundreds of thousands of dollars in reward. In those countries, government funding supports the Olympic program. 
Thus, there are many reasons to avoid the further marketization and professionalization of college sports. Fortunately, there is a more attractive reform path: reinforce the educational model.

One logical way to confront the tendency toward the subordination of academics to athletics is to revisit the major source of the post-1984 commercialization juggernaut: the antitrust treatment of college sports. ${ }^{127}$ By legislating a partial and conditional antitrust exemption for the governing body of college sports, it would be possible not only to blunt the incentives that are corroding academic integrity but also to arrest the runaway expenses that are burning a deep hole in the pockets of athletic programs and, therefore, also of university budgets.

That is, on the condition that the NCAA enacts certain reforms to promote academic integrity and the fair treatment of athletes, Congress would grant an antitrust exemption in certain commercial areas and elsewhere where commercial and academic concerns overlap. Congressional involvement is necessary because rules such as controlling compensation to athletes, compensation to coaches, the value and number of athletic scholarships, the number of preseason and postseason tournaments, the limit of twenty countable hours of practice and games during the week, and so forth are designed to protect the separation between college and professional sports. But as argued earlier, there are no clearcut balancing tests or other mechanisms to make policy judgments cleanly about whether they are in fact justified and necessary. The answers end up depending on the judgment of particular courts and not on any clear objective standards.

A limited antitrust exemption would seek to define clearly those NCAA rules that could not be challenged under the Sherman Antitrust Act on the grounds that they are controls necessary to achieve the priority purposes of higher education in the conduct of intercollegiate athletics as an extracurricular activity.

Unquestionably, a fundamental function of the NCAA is to maintain a clear line of demarcation between college sports as an extracurricular activity secondary to the academic responsibilities of students, on the one hand, and professional sports - which require a time and effort priority on athletic excellence and revenue decisions inappropriate for a nonprofit educational institution —on the other hand. Actions that should be considered the legitimate functions of a nonprofit national intercollegiate athletics governance association typically include, among others, those that: (1) control the cost of athletics (athletic programs are heavily subsidized by student fees and general funds) so the support of athletics programs does not damage the ability of the institution to support its primary academic programs, (2) prevent the operation of varsity sport programs from conflicting with student academic responsibilities (e.g., controlling sport schedules so they do not conflict with class attendance, restricting athletic participation of students not performing academically, and limiting time spent on sport activities in order to allow sufficient time for attending class and studying), (3) enhance competitive balance among schools and conferences, and (4) protect the health and welfare of college athletes (e.g., providing proper health insurance coverage and safeguards after injury before returning to play).

Many of these actions also have commercial implications and have been or will be the target of antitrust lawsuits absent a limited antitrust exemption. A limited antitrust exemption that applies only to these legitimate categories of controls will enable institutions of higher education to collectively enact needed reforms without fear of legal liability. Such a limited exemption is both justifiable and necessary. Antitrust lawsuits represent huge costs for legal representation, participation in court cases,

127. As noted above, a major factor that facilitated and deepened the commercialization of college sports was the 1984 Supreme Court decision in Board of Regents, where the Supreme Court ruled that the NCAA's existing national television contracts with $\mathrm{ABC}$ and $\mathrm{CBS}$ were illegal restraints of trade. The ruling set the stage for subsequent conference contracts with the television networks, a mergers and acquisitions phase of conference growth which redrew geographical conference lines to maximize the value of media deals, and heightened incentives to compromise academic integrity in pursuit of athletic glory. 
and payment of damages. ${ }^{128}$ These funds would otherwise be available to advance the NCAA's and its member institutions' nonprofit educational purposes.

Below we elaborate on what areas might be granted an antitrust exemption and on the conditions the NCAA must follow to qualify for the partial exemption.

\section{A. Potentially Exempt Areas}

First, the NCAA would be exempt from imposing limits on the salaries paid to head and assistant football and men's basketball coaches, ${ }^{129}$ which often exceed the salaries of the universities' presidents by a factor of five to ten. Over 110 college football and basketball coaches received salaries exceeding \$1 million in FY 2014, three dozen exceeded \$3 million, and fifteen exceeded \$4 million. The highest paid coach was Nick Saban at Alabama, with a salary of $\$ 7.2$ million plus potential bonuses of $\$ 700,000 .{ }^{130}$ His contract is guaranteed with increases through the 2021-2022 season. Saban's staff earned an additional $\$ 5.2$ million in salary in 2014, including a $\$ 525,000$ salary for the strength and conditioning coach. Thus, total football coaching compensation at Alabama before handsome benefits and rich perquisites exceeded $\$ 13$ million. Perquisites generally include free use of cars, housing subsidies, country-club memberships, private jet service, exceptionally generous severance packages, and more. ${ }^{131}$ The coaches also have handsome opportunities to earn outside income via apparel or sneaker endorsements, the lecture circuit, summer camps, and book contracts. In forty states, the head football or basketball coach on a college team makes more in guaranteed compensation than the governor. ${ }^{132}$

Defenders of multi-million-dollar head coaches' salaries argue that coaches' compensation packages are driven by market forces. Perhaps that is true, but the market for coaches is sustained by artificial factors: (1) no compensation is paid to the athletes, (2) intercollegiate sports benefit from substantial tax privileges, (3) no shareholders demand dividend distributions or higher profits to bolster stock prices at the end of every quarter, (4) athletic departments are nourished by university and statewide financial support, and (5) coaches' salaries are frequently negotiated by athletic directors whose own worth rises with the salaries of their employees.

In a normal competitive market, college football and basketball coaches would not be compensated almost at the same level as NFL and NBA coaches. The top thirty-two college football programs generate revenues between $\$ 35$ million and $\$ 150$ million; NFL teams generate between $\$ 296$ million and $\$ 620$ million. ${ }^{133}$ The top thirty college men's basketball teams generate roughly between $\$ 10$

128. Noteworthy is that antitrust damages are trebled under the Sherman Act. This is an impetus for the parties to reach a settlement. Settlements resolve matters only between the particular parties and do not foreclose future cases brought by a different set of plaintiffs. See, e.g., White v. Nat'l Collegiate Athletic Ass'n, Case No. CV-06-0999-RGK (C.D. Cal. 2006) (discussing allegations regarding the GIA Cap that settled, allowing for a different set of plaintiffs in O'Bannon to bring similar allegations without the existence of contrary precedent).

129. Such limits would be imposed regardless of the source of the funding.

130. For the 2016-2017 season, Jim Harbaugh at the University of Michigan will be compensated to the tune of $\$ 9$ million. Mark Snyder \& Steve Berkowitz, Jim Harbaugh, U-M Agreed to \$2-Million Additional Compensation in June, DetroIT Free Press \& USA Today (Aug. 18, 2016), http://www.freep.com/story/sports/college/university-michigan/wolverines/ 2016/08/17/michigan-jim-harbaugh-contract/88910306/.

131. One eye-popping severance clause appeared in the contract of Mike Sherman, Texas A\&M's football coach, who, if terminated, would have been paid $\$ 150,000$ a month for the remainder of his contract that would have amounted to a "\$7.8 million golden handshake.” Andrew Zimbalist, Circling the Bases: Essays on the Challenges and Prospects of the SPORTS INDUSTRY 177 (2011).

132. Reuben Fischer-Baum, Infographic: Is Your State's Highest-Paid Employee a Coach? (Probably), DEADSPIN (May 9, 2013, 3:23 p.m.), http://deadspin.com/infographic-is-your-states-highest-paid-employee-a-co-489635228. In the forty-first state, New Hampshire, the head ice hockey coach earns more than the governor.

133. The revenue estimates for NBA and NFL teams come from the 2015 Forbes annual reports. Those for college football and basketball teams come from the 2015 NCAA Revenues and Expenses biannual report. 
million and \$40 million in revenue, while NBA team revenues are from $\$ 110$ million up to $\$ 293$ million. Thus, NFL team revenues are 8.4 times greater than revenues of college football teams at the lower end and 4.1 times at the top end; NBA team revenues are 11.0 times greater than those in college basketball at the lower end and 7.3 times greater at the top end. Yet the compensation packages of college and professional coaches in football and basketball are strikingly similar.

Most FBS college coaches are paid the value created by the players they recruit. Much of the recruiting is done by assistant coaches, and much of the allure of the recruitment effort is a function of the school's history, brand and facilities. Moreover, the coaches' bloated compensation packages are almost all economic rent. That is, they are paid way beyond what they would have to be paid to induce them to offer their labor in the college coaching market. If the Nick Sabans and John Caliparis of the college coaching world did not coach in an FBS program, their next best alternative employment opportunity likely would be coaching at FCS or Division II or III, or even high school. ${ }^{134}$ Accordingly, if the NCAA placed, say, a $\$ 400,000$ limit on coaches' compensation packages, ${ }^{135}$ it would not affect the quality of coaching or the level of intercollegiate competition. Stated differently, it would not affect the allocation of coaching resources or diminish the entertainment value of college sports. Further, it would eliminate the sending of twisted signals to undergraduate students about the importance of the college president or the professoriate relative to the head football or basketball coach.

Second, we propose a cap on spending to build new facilities that would be exempt from the antitrust laws. ${ }^{136}$ The cap would be geared toward preventing extraordinary expenses on athleteonly facilities, like those built at Clemson that include laser tag, miniature golf, beach volleyball, and other amenities divorced from the playing field and geared towards retaining recruiting advantages.

We propose that a third exempt activity would be rules reducing the size of FBS football teams. NCAA rules currently allow FBS football teams up to eighty-five scholarships. Capping the number at sixty (or fewer) would not devalue college football. ${ }^{137}$ NFL teams have a maximum active roster of forty-five, plus a maximum inactive roster of eight additional players. ${ }^{138}$ The average FBS team has thirty-five walk-ons

134. Of course, some college coaches would attempt to coach in the NFL or NBA. Both Calipari and Pitino, for instance, have done that and failed. Coaching in college and in the pros require rather different skill sets. In any event, to the extent that some college coaches go to the pros (and Calipari, for one, has continued to receive interest from some NBA owners), the pro coaches they replace would become available to the top college programs. Thus, the talent level of coaching and the quality of the college product would not be materially affected by capping coaches' compensation. Some observers have pointed out that if student-athletes were paid, the excessive payment of salaries to coaches would self-adjust downward. While this is a likely occurrence, it would take years to fully play out as existing long-term contracts would have to expire and the culture of the marketplace would have to adjust. The same relationship holds with excessive spending on facilities, but in this case the adjustment would take decades because the useful life of new stadiums, arenas and training centers is at least thirty years. During the adjustment periods, larger losses would be sustained by athletic programs.

135. The $\$ 400,000$ figure is illustrative. The actual cap should approximate the coaches' reservation wage; that is, the compensation they would require in order to induce them to offer their labor. In turn, this level will be approximated by the opportunity cost or the next best compensation package they could receive if they were not coaching at the top college level.

136. This cap may be modified to allow catch-up spending for schools that had not made a certain level of facility investment over the previous period.

137. College coaches have protested that college football teams cannot be properly compared to professional teams. The latter, they say, can always call up reserves when players get injured, but college teams must have players on their rosters to replace the injured. First, NFL teams have only a maximum of sixteen players on reserve and practice squads to complement their forty-fivemen active rosters. Second, the NCAA Injury Surveillance System Summary reports that for the 2000-2001 season, the seriousinjury rate during games in football was 14.1 per 1,000 exposures, while the rate in football practices was 1.6 per 1,000 . If we assume that sixty players enter a game and the team plays thirteen games during the year (that is, including a postseason game), then the average total number of serious injuries (where a player is out seven or more days) from games is eleven per year. If on average, each such player misses two games, then the average number of game-injured players is 1.69 per game. Performing a similar calculation for practice-injured players' yields 1.48 per game for a combined average of 3.17 injured players per game. This hardly constitutes a justification for carrying eighty-five scholarship and 120 total players on an FBS team.

138. NFL teams are also allowed to carry up to eight additional players on their practice squads. 
plus eighty-five scholarship players-120 players in all! ${ }^{139}$ If football scholarships were cut to sixty, the average college would probably save close to $\$ 1.5$ million annually ${ }^{140}$ - easily enough to finance an average FBS soccer team plus an average FBS golf team, or an FBS tennis team plus gymnastics team, and have several hundred thousand dollars left over. ${ }^{141}$ Even assuming the number of walk-ons would not increase with the lower scholarship limit, the average squad size would still be over ninety. No rational coach would dare to argue that a football team size of ninety-plus players is inadequate.

A fourth exempt policy would be restrictions on the payment of salaries to athletes for the performance in their sport. Athletes could receive full scholarships for participating on their team, including a cost of living allowance, third-party payments up to certain limits for NILs, and other elements to be discussed below, but they could not be paid directly for what they do on the football field or basketball court. This is basically the concept of amateurism (i.e., no compensation for playing a sport) that is applied by the AAU and other amateur sports organizations in the United States.

We further suggest other areas of exemption that lean more toward the academic integrity end of the spectrum, including restrictions on weeknight football and basketball games, the length of competitive seasons, the number of in-season and out-of-season practice and game hours per week, inter alia. ${ }^{142}$

\section{B. Conditions for Granting Partial Exemption}

One can imagine a variety of conditionality stipulations geared toward insuring that athletes are treated fairly and that academic fraud is minimized, if not extirpated. For the NCAA to be granted a partial antitrust exemption, it would have to enact and implement certain proeducational and health, safety, and fairness reforms. Congress would mandate these conditions. A suggested, noninclusive list follows.

Initial eligibility standards need to be strengthened. Since the 2003 sliding scale was introduced, it is possible for athletes to gain full initial eligibility and still receive a zero score on standardized tests by attaining a 3.55 grade point average. ${ }^{143}$ If, however, the high school rigs the athlete's classes and teachers to achieve this GPA, then the initial eligibility standard is a mockery. Similar issues apply to the continuing eligibility standards and to the APR metric. New, more meaningful standards need to be set and become conditions for the limited antitrust exemption.

The NCAA would also be required to put in place appropriate due process procedures for all schools, administrators and athletes who are accused of transgressions. These include notice of allegations, fair hearing processes (including the exchange of evidence and cross examination rights of both parties), and adequate appeal procedures.

Athletes' rights must be fortified, including the following health, safety, and fairness protections:

- Schools should pay for broad injury insurance coverage.

- Athletes should have the right to work with counsel or an agent prior to deciding upon entering a professional draft or participating in a sports league combine.

- All academic support programs for athletes should be removed from the athletics department and put entirely under academic control.

139. NCAA, 2005-06 NCAA Gender Equity Report, 27 (Oct. 2008), http://www.ncaapublications.com/productdownloads/ GER06.pdf.

140. This number is based on twenty-five men's scholarships at $\$ 40,000$ each, plus the possibility of savings on women's scholarships and the probable reduction in athletic support staff and equipment.

141. NCAA, 2004-08 NCAA Revenues and Expenses of Division I Intercollegiate Athletics Programs Report, 37 (October 2009), http://www.ncaapublications.com/productdownloads/RE09.pdf.

142. Many courts might classify these as noncommercial restraints. If so classified, an antitrust exemption would be redundant.

143. This sliding scale eligibility was introduced after a two-decade struggle with the Black Coaches Association that claimed a hard cutoff on standardized tests was arbitrary and discriminatory toward minority athletes. It is interesting to note the growth in the participation of black athletes in college sports actually was more rapid prior to 2003 than it was after 2003. 
- Transfer athletes should not lose a year of eligibility.

- Athletes should be guaranteed a four-year scholarship.

- Stricter rules regarding time commitments by athletes should be imposed.

- Whistleblower protection should be provided to anyone reporting transgressions with retaliation explicitly prohibited.

- Every school should be required to certify Title IX compliance.

Additionally, the NCAA should run the national Championship Football Playoff (CFP) system, inaugurated in 2014-2015, just as it runs all other (eighty-nine in total) NCAA championships. The CFP, which is the only national championship not controlled by the NCAA, generates more than $\$ 600$ million in revenue, over three-fourths of which is distributed to the Power Five conferences. This skewed distribution, at once, enhances the financial incentives toward victory at any cost and, importantly, diminishes funding for Olympic sports and women's sports throughout the NCAA's three divisions. Thus, a condition for receiving a partial antitrust exemption should be to bring the football playoff into the fold.

Finally, NCAA governance should be reformed with more equal balance among the Divisions and within Division I. The NCAA's boards, councils, and committees should have more independent yet informed members. We do not recommend a specific structure at this time other than specifying that the entire membership should not be controlled by the Power Five powerhouses. However, we agree with the Dodd-Frank Wall Street Reform and Consumer Protection Act of 2010 (Dodd-Frank), ${ }^{144}$ insofar as it requires the boards of directors of for-profit corporations to be comprised of a majority of independent directors and requires that compensation and audit committees must be made up entirely of independent directors. Other helpful models include the Amateur Sports Act, ${ }^{145}$ which requires that the national governing boards for each Olympic sport include individuals not affiliated with any amateur sports organizations and who would represent the American public's interests. If the NCAA and its membership are unable to restructure and its Board members are unable to exhibit a fiduciary duty to the NCAA as a whole and not just to individual divisions or groups of schools, then Congress should consider creating a new federally created nonprofit organization or an independent federal regulatory commission ${ }^{146}$ to govern intercollegiate athletics.

\section{Precedent of Antitrust Exemptions}

The solution proposed herein is not extraordinary. ${ }^{147}$ Congress has enacted limited antitrust exemptions in numerous industries - ranging from the hog industry, ${ }^{148}$ to railroads, ${ }^{149}$ to soft drinks, ${ }^{150}$ to the

144. 12 U.S.C. $\S 5301$, et seq. (2010). Sarbanes-Oxley Act of 2002 first enacted some of these requirements. 15 U.S.C. 7241 (2002); 18 U.S.C. 1350 (2002).

145. 36 U.S.C. $\S 220504(b)(1998)$.

146. The Drake Group, a national organization committed to academic integrity in collegiate sport, has proposed similar reforms, including the establishment of a Presidential Commission in Intercollegiate Athletics Reform and a bill entitled the College Athletics Act. It further proposes a federally chartered nonprofit organization to replace the NCAA. See The Drake Group (n.d.), Academic Integrity in Collegiate Sport, website, http://thedrakegroup.org. See also GuRnEy, Lopiano, \& ZimBalist, Unwinding Madness, supra note 125.

147. Arguably, regulating college athletics including eligibility, scholarships, scheduling, and spending is not so different from regulating college financial assistance such as covered in the Higher Education Act that includes rules on loan limits, accreditation, determining who gets money, how much and when, etc. And regulating gender equality in college sports (e.g., Title IX, 20 U.S.C. $§ 1681$ et seq.) demonstrates that Congress believes it is appropriate to impose legislation in this important area.

148. Anti-Hog-Cholera Serum and Hog-Cholera Virus Act, 7 U.S.C. § 852 (1935).

149. Railroad transportation exemption, 49 U.S.C. $\S 10706$ (1996).

150. Soft Drink Interbrand Competition Act.,15 U.S.C. $\S \S 3501-03$ (1980). 
insurance industry, ${ }^{151}$ to sports, and most significantly to higher education. Certain statutory antitrust exemptions involving the sports industry and higher education are discussed below. ${ }^{152}$

\section{A. Sports Broadcasting Act}

The Sports Broadcasting Act of 1961 (SBA) provides limited immunity from antitrust litigation to the four major professional sport leagues for selling horizontally pooled broadcasting rights to over-the-air channels. ${ }^{153}$ The SBA puts restrictions on broadcasting games on Friday nights and Saturday. Its limited immunity is made clear:

[the SBA] shall [not] be deemed to change, determine, or otherwise affect the applicability or nonapplicability of the antitrust laws to any act, contract, agreement, rule, course of conduct, or other activity by, between, or among persons engaging in, conducting, or participating in the organized professional team sports of football, baseball, basketball, or hockey. ${ }^{154}$

\section{B. NFL-AFL Merger}

In 1966, Congress passed a very limited and targeted antitrust exemption to permit the combination of the NFL and AFL. ${ }^{155}$

\section{Ted Stevens Olympic and Amateur Sports Act (ASA)}

Particularly to clean up amateur sports, Congress passed the Amateur Sports Act (ASA) in 1978 (subsequently amended in 1998), ${ }^{156}$ creating a vertical structure for the management of certain amateur sports in the United States. ${ }^{157}$ While Congress did not expressly exempt action taken under the ASA's direction from the federal antitrust laws, nevertheless, courts have found an implicit exemption from antitrust laws where there exists a plain conflict between the antitrust laws and ASA regulatory provisions. ${ }^{158}$

151. McCarran-Ferguson Act, 15 U.S.C. $\S \S 1011-15$ (1945).

152. Various bills have been proposed to provide the NCAA an antitrust exemption that would permit greater benefits to athletes. For example, in 1991, U.S. Representative Tom McMillen (a former professional basketball player) introduced legislation in Congress to grant the NCAA a five-year antitrust exemption in exchange for NCAA reform regarding revenue sharing and due process for those accused of violations of NCAA rules. The bill, entitled the Collegiate Athletic Reform Act, would have also authorized the payment of a $\$ 300$ per month stipend and five-year athletic scholarships for student-athletes in good academic standing. The proposal failed to become law. Brian L. Porto, the Supreme Court and the NCAA 19-92012) (citing Welch Suggs, Football, Television, and the Supreme Court, CHRoN. Higher Educ., July 9, 2004, at A17, A32-A33).

153. Sports Broadcasting Act of 1961, 15 U.S.C. $\$ 1291$ (2000) (stating that "[t]he antitrust laws, as defined in section 1 of the [Sherman] Act[,] ... shall not apply to any joint agreement . . . by which any league of clubs participating in professional football, baseball, basketball, or hockey contests sells or otherwise transfers all or any part of the rights of such league's member clubs in the sponsored telecasting of the games... engaged in or conducted by such clubs").

154. 15 U.S.C. $\S 1293(2000)$.

155. Pub. L. No. $89-800 \S 6($ b)(1) (codified at 15 U.S.C. $\S 1291$ (1986)).

156. 36 U.S.C. $\S 220501$ et seq. (2006).

157. 36 U.S.C. $\S 220503$ (1998).

158. For example, in Behagen v. Amateur Basketball Ass'n of the U.S., the Tenth Circuit held the degree to which private action was necessary to implement the intent of Congress in passing the ASA meant National Governing Bodies (NGBs) could exercise monolithic control over a particular sport, and NGBs could exercise such control without fear of violating the federal antitrust laws. 884 F.2d 524, 529-30 (10th Cir. 1989). See also Eleven Line v. N. Tex. State Soccer Ass'n, 213 F.3d 198, 204 (5th Cir. 2000); Gold Metal LLC d/b/a Run Gum v. USA Track \& Field, Case No. 6:16-cv-00092-MC (D. Or. 2016) Doc. 52 (finding an implied antitrust immunity applies to the ASA). 


\section{Curt Flood Act}

The Curt Flood Act of 1988 removes Major League Baseball's presumed antitrust exemption (judicially conferred in 1922) in the area of labor relations. ${ }^{159}$ There continues to be much litigation regarding this judicial exemption.

\section{E. Improving America's Schools Act}

The Improving America's Schools Act of $1994^{160}$ exempts from the antitrust laws agreements to admit students on a need-blind basis by institutions of higher education. The Act permits, inter alia, schools jointly "to use common principles of analysis for determining the need of such students for financial aid if the agreement to use such principles does not restrict financial aid officers ... in their exercising independent professional judgment with respect to individual applicants for such financial aid." The Act does not permit schools to agree on which particular students are entitled to aid.

\section{F. Medical Resident Matching Program Exemption ${ }^{161}$}

Following an antitrust lawsuit filed by medical students challenging national resident matching programs, Congress in 2004 partially exempted the existing medical resident matching programs from antitrust laws, stating that it is not "unlawful under the antitrust laws to sponsor, conduct, or participate in a graduate medical education residency matching program...."162 The amendment also made inadmissible in federal court evidence of exempted conduct to support claims that allege violations of the antitrust laws. ${ }^{163}$ The exemption does not permit agreements to fix the amount of the stipend or other benefits received by students participating in such programs. ${ }^{164}$

These acts demonstrate that Congress protects certain activities in sports and higher education from the antitrust laws when it deems fit. ${ }^{165}$ It defines antitrust exemptions specifically and narrowly. Here too the exemption should be narrowly defined.

\section{Conclusion}

In summary, intercollegiate sports are distinct from other extracurricular activities in higher education and from professional sports. Thorough reform of the existing system is needed. The NCAA has made mostly incremental efforts at reform, while public policy has been inactive regarding intercollegiate athletics. The most substantial challenges for reform have come from piecemeal litigation. It is time for systemic change.

159. Congress ensured the limited scope of its intervention by expressly stating that "the passage of this Act does not change the application of the antitrust laws in any other context or with respect to any other person or entity." 15 U.S.C. § 26 b.

160. 20 U.S.C. ch. 70, subch. I $\S 6301$ et seq. (2015).

161. 15 U.S.C. $\$ 37(1997)$.

162. 15 U.S.C. $\$ 37 b(2)(2004)$.

163. 15 U.S.C. $\S 37 b(b)(2)(2004)$.

164. 15 U.S.C. $\S 37 b(b)(3)(2004)$.

165. There also have been discussions in favor of an antitrust exemption for the NCAA as it relates to Title IX. The Commission on Opportunity in Athletics, empaneled from 2002-2003 (and, notably, made up primarily of representatives from Division 1-A schools), made a recommendation to the Secretary of Education that an antitrust exemption be created to reduce spending in intercollegiate athletics. Several years later, the Women's Sports Foundation issued a report in favor of an antitrust exemption that would allow the NCAA to reduce expenditures, including coaches' salaries, due to the negative effects that the "arm's race" can have on student-athletes and the institutions' educational efforts. While these efforts did not gain traction at the time, they too are examples of support for an antitrust exemption, including an exemption for regulations imposing restraints on athletics spending, so long as the cost-savings are used in furtherance of education or student-athletes' welfare. 
First, we have demonstrated that the economic environment of intercollegiate sports is unstable and unsustainable. Growing deficits in athletic departments are depleting academic resources and undermining the educational process. Indeed, college athletic programs are draining central educational budgets of hundreds of millions of dollars annually. And the drain is only growing.

Second, we have argued that it is unsatisfactory to apply an antitrust framework to college sports with analyses that (1) distinguish between commercial and noncommercial purposes and effects, and (2) analyze procompetitive and anticompetitive effects and less restrictive alternatives. Moreover, court decisions are limited to particular claims. They cannot take into account all the broader social policy implications of their decisions that impact the future of intercollegiate sports with its many dimensions and stakeholders. And tens of millions of dollars - along with the attention of thousands of lawyers, administrators, and others - are being misspent on litigation.

For these reasons, congressional intervention is necessary to address the policy decision of how to preserve the educational pursuit of universities and colleges and their college athletes, while saving the aspects of intercollegiate sports that we cherish and that nourish the well-rounded development of college athletes. We believe such intervention should be narrowly tailored and limited to specific concerns facing the NCAA and college athletes today and should be informed by analogous statutory antitrust exemptions and judicial precedents. Accordingly, the exemption should be conditioned on the implementation of (1) cost saving measures (e.g., capping coaches' salaries and facilities spending) and (2) measures ensuring the health and safety of athletes and the primacy of academics in intercollegiate sports.

\section{Acknowledgements}

The authors thank C. Scott Hemphill, Matthew Mitten and Stephen F. Ross for helpful comments, and Erin Halstead for excellent research assistance.

\section{Declaration of Conflicting Interests}

The author(s) declared no potential conflicts of interest with respect to the research, authorship, and/or publication of this article.

\section{Funding}

The author(s) received no financial support for the research, authorship, and/or publication of this article. 